\title{
Symbolika eklezjalna Jerozolimy a polemika antydonatystyczna w Afryce Rzymskiej
}

\begin{abstract}
Donatyści ${ }^{2}$ stanowili problematyczny element panoramy chrześcijaństwa w Afryce Rzymskiej. Kryzys donatystyczny opisywano już wielokrotnie pod względem faktograficznym i doktrynalnym. Wskazano na najważniejsze punkty kontrowersji, ale także na poboczne kwestie. Dociekano przy tym ich głębszych przyczyn i skutków ${ }^{3}$. Refleksja doktrynalna donatystów niewątpliwie nie osiągała najwyższego poziomu, gdyż ma się do czynienia $z$ teologią nieuczoną i o charakterze ludowym ${ }^{4}$. Ich argumentacja koncentrowała się wokół zagadnień związanych z sakramentami i Kościołem. Nie były to jednak jedyne cechy charakterystyczne tego ruchu. W polemice antydonatystycznej można znaleźć wiele wątków eklezjologicznych. Ich drobiazgowe wyodrębnienie i omówienie nie stanowi jednak przedmiotu refleksji podejmowanej w tym artykule. Wydaje się jednak, że rzadko który z symboli Kościoła tak zafascynował pisarzy
\end{abstract}

1 Dr hab. Mieczysław Celestyn Paczkowski OFM, prof. UMK, pracownik Katedry Patrologii i Historii Kościoła na Wydziale Teologicznym Uniwersytetu Mikołaja Kopernika w Toruniu; e-mail: celestyn@umk.pl; ORCID: 0000-0002-4045-2314.

2 Donatyzm wywodzi się od imienia swego założyciela - Donata, biskupa w Numidii, a następnie Kartaginy. Był on rygorystą i człowiekiem energicznym. Zdecydowanie kwestionował prawa cesarza do decydowania w sprawach kościelnych. $\mathrm{Z}$ tego względu postrzegano go jako ucieleśnienie ideału całkowitego odseparowania Kościoła od świata. Por. W.H.C. Frend, Donato di Cartagine, NDPAC 1 1495-1498. Zob. S. Adamiak, Deo Laudes. Historia sporu donatystycznego, Warszawa 2019, s. 45-46.

3 Wśród syntetycznych opracowań warto wskazać następujące: W.H.C. Frend, The Donatist Church. A Movement of Protest in Roman North Africa, Oxford 1952; E. Romero Pose, Medio siglo de estudios sobre el donatismo (De Monceaux a nuestros dias), ,Salmaticensis” 29 (1982) s. 81-99; S. Lancel - J.S. Alexander, Donatistae, AL II/34, Basel 1999, s. 606-638.

4 To charakterystyczna cecha chrześcijaństwa afrykańskiego. 
chrześcijańskich jak obraz Jerozolimy. Miasto Boże, podobnie jak Kościół, jawiło się jako rzeczywistość ziemska i niebiańska, ogarniając sferę historyczną i wkraczając w świat niewidzialny. Na obraz Jerozolimy składały się odnośniki do konkretnej rzeczywistości i historii oraz wątki eschatologiczne i duchowe, co podkreślali prawowierni autorzy. Były to również elementy zbiorowej świadomości afrykańskich schizmatyków.

\section{Zręby eklezjologii a donatyzm w rzymskiej Afryce}

Eklezjologia stanowiła serce przesłania donatystycznego. Na niej osadzona była również tożsamość tej grupy i praktyka życia ${ }^{5}$. Nie bez powodu $\mathrm{w}$ donatyzmie dostrzegano przede wszystkim rewindykacje świętości i czystości Kościoła. Donatyści włączyli swoją teologię w praktykę specyficznego życia. Schizma afrykańska nawiązywała do idei wspólnoty wybranych przez ascezę i męczeństwo, realizując pasywny opór wobec świata i oczekując bliskiej paruzji. Jednocześnie donatyzm to starcie dwóch eklezjologii. Z jednej strony „Kościół świętych" (eccelesia sanctorum), a z drugiej Kościół rezygnujący z egzaltacji religijnej i godzący się na brak nieskazitelności swoich wyznawców. Na dalszy plan należałoby być może odsunąć ambicje i animozje wśród duchownych, kwestie nacjonalizmu problemy społeczno-ekonomiczne ${ }^{6}$ i stosowanie przemocy ${ }^{7}$.

Refleksje nad naturą Kościoła w Afryce północnej ewoluowały przez dłuższy okres. Należałoby sięgnąć po refleksje Tertuliana czy jeszcze wcześniejszych autorów. W tym najwcześniejszym okresie idea Kościoła, jako alternatywy dla otaczającego chrześcijan wrogiego świata, była w zarodku i wizja autorów afrykańskich nie odbiegała od ogólnych przekonań wierzących w Chrystusa. Jednak u donatystów w różnym stopniu to przeświadczenie przetrwało także później. Należałoby być może wziąć pod

5 Por. E. Zocca, L'identità cristiana nel dibattito tra cattolici e donatisti, ASE 21/1 (2004) s. 109-130.

6 Donatyzm, ze względu na swoją szczególnego rodzaju teologię o znamionach politycznych, mógł być uważany za „rewolucyjny” w kwestiach społeczno-moralnych. Zob. np. S. Jóźwiak, Państwo i Kościół w pismach św. Augustyna, Lublin 2004, s. 141-144.

7 O stosowaniu przemocy w sporze donatystycznym, zob. Adamiak, Deo Laudes, s. 125-126. W myśl Reguły VI Tykoniusza (Dominus et Ecclesia una caro est) ten, kto wierzy, że Słowo stało się ciałem, nie może prześladować Słowa w ciele, czyli w Jego sługach. Por. D. Budzanowska, O rekapitulacji wedtug Tykoniusza, WST 26/2 (2013) s. $87-89$. 
uwagę nie tyle wątki protodonatystyczne, co raczej elementy eklezjologii przyswojone przez tę sektę.

Z eklezjologią donatystyczną zharmonizowały się przekonania eschatologiczne. Z przeświadczenia o stanie prześladowania wyłonił się obraz wybranej cząstki, prawdziwej „reszty Izraela”, którą stanowili członkowie sekty ${ }^{8}$. Kontrast pomiędzy rzeczywistością historyczną a oczekiwaniem eschatologicznym stanowił ważny element w duchowości i nauczaniu Kościoła afrykańskiego. Prowadziło to do uduchowienia biblijnych obrazów Jerozolimy i ziemi odkupienia, co widać u Tertuliana nazywanego ,prekursorem donatystów”. W jego przekonaniu za "Ziemię Świętą", która dla Żydów znajduje się w Judei, powinno być uważane ciało Zbawiciela. Z tej „Ziemi” wypływają „mleko” i „miód” nadziei chrześcijańskiej. „Ziemię Świętą” stanowią również chrześcijanie, ponieważ zamieszkuje w nich Duch Święty; to również „świątynia Boga i Jerozolima”. Z „Ziemią" związane są dary chleba, oliwy, wody i wina, które dla Tertuliana stają się zapowiedziami sakramentów ${ }^{10}$. Znajdują one potwierdzenie również $\mathrm{w}$ ziemskiej rzeczywistości Kościoła ${ }^{11}$.

Nie ulega wątpliwości, że donatyści odwoływali się do autorytetu św. Cypriana z Kartaginy ${ }^{12}$. W Afryce północnej istniała swego rodzaju wspólna płaszczyzna refleksji eklezjologicznej, do czego w znacznej mierze przyczynił się ten święty biskup Kartaginy. Znamienna jest jednak jego postawa polegająca na daleko posuniętej rezerwie wobec niektórych koncepcji eschatologicznych. Wiązało się to z postawą antymontanistyczną Cypriana, mimo wpływu środowiska i przywiązania do „mistrza” - Tertuliana. Biskup Kartaginy mocno akcentował eklezjalny charakter dziejów Jerozolimy, mówiąc o wspólnocie apostolskiej opisanej na kartach Dziejów Apostolskich (por. Dz 4,32) jako wzorze dla wszystkich chrześci-

8 Odnośnie do tej autodefinicji donatystów, por. M. Tilley, Sustaining Donatist SelfIdentity. From the Church of the Martyrs to the Collecta of the Desert, JECS 5/1 (1997) s. 2135. Donatyści mówili o sobie także „święci” lub „sprawiedliwi i czyści”. Zob. M. Tilley, The Bible in Christian North Africa. The Donatist World, Minneapolis 1997, s. 178.

9 M.A. Gaumer, The Evolution of Donatist Theology as Response to a Changing Late Antique Milieu, „Augustiniana” 58/3 (2008) s. 177.

10 Por. Tertullianus, De resurrectione 26, 41.

11 Warto przypomnieć znane twierdzenie Tertuliana o tym, że heretycy są sierotami, ponieważ nie posiadają oni Kościoła, czyli matki, którą jest niebiańskie Jeruzalem. Por. Tertullianus, De praescriptione haereticorum 42, 10. Według Tykoniusza nie można dostąpić łaski Bożej i „mieć Ducha Bożego”, nie będąc w Kościele. Tichonius Afer, Commentarius in Apocalypsis ad 5, 6.

12 Zwrócił na to uwagę Optat z Milewy. 
jan ${ }^{13}$. Tego typu wątki przywoływali donatyści, aby usprawiedliwić swoją schizmę. Chociaż schizmatycy afrykańscy zniekształcali doktrynę wielkiego Ojca Kościoła, to przez dziesięciolecia ich twierdzenia pozostawały bez adekwatnej odpowiedzi ze strony katolików. Obawiano się być może, że w wyniku polemiki mogłaby ucierpieć reputacja św. Cypriana jako teologa i pasterza ludu Bożego.

Pomniejsi pisarze chrześcijańscy z terenu rzymskiej Afryki, mimo że często nie grzeszyli oryginalnością, byli mistrzami w ustalaniu i szczegółowym opracowywaniu wyrazistych antytez. W kwestii Jerozolimy nie ograniczano się do ogólnych opisów, ale stosowano porównania. Tak jest w przypadku anonimowego dzieła De duobus montibus. Wyróżnia się ono niekonwencjonalną egzegezą Pisma Świętego oraz archaicznymi wątkami w eklezjologii. Traktat przedstawia góry Synaj i Syjon jako dwie antytetyczne rzeczywistości. Różnica nazw, uwydatniona według latina interpretatio $^{14}$, oznacza odrębne stopnie „łaski i chwały"15.

Donatyści, jako prawdziwe „pokolenie Pańskie”, używali metafory świętej góry Syjon i położonego na niej miasta uważanego za metaforę Kościoła. Dodawano do tej symboliki przeciwieństwo dwóch gór Starego i Nowego Przymierza, interpretowane również w sensie eklezjologicznym. Ten obraz przekształcił się w wizerunek dwóch Kościołów. Tylko Jerozolima, usytuowana na ,świętej górze”, w duchu interpretacji eklezjologicznej o radykalniejszej tendencji, może być prawdziwym Kościołem ${ }^{16}$.

Według pseudocyprianowego De duobus montibus dzięki głoszeniu Ewangelii, ,[poganie] weszli [...] do miasta odnowionego i świętego, którym jest Kościół duchowy"17. Nie ulega wątpliwości, że inspirację autora stanowi Ap $21^{18}$. Autor odwołuje się do perspektywy innych pism NT

13 Por. Cyprianus, De Ecclesiae catholicae unitate 25. Zob. także: Augustinus Hipponensis, Sermo 356, 1. Na temat wykorzystania refleksji Cypriana przez Augustyna, zob. M.A. Gaumer, Augustine's Cyprian. Authority in Roman Africa, Leiden - Boston 2016.

14 Potwierdza to etymologia. ,«Syjon» w thumaczeniu oznacza «pokusa do gniewu» $\mathrm{i}$ «miejsce obserwacji» [...]. Nie chodzi więc o tę samą górę (tj. Synaj i Syjon) [...]. Góra Syjon jest niebiańska i duchowa”. Ps-Cyprianus, De duobus montibus 2.

15 Por. Ps-Cyprianus, De duobus montibus 1, 2. Anonimowy autor utożsamia góry Synaj i Syjon z dwoma Testamentami. Por. Ps-Cyprianus, De duobus montibus 11, 1, ed. B. Burini, Pseudo Cipriano. I due monti Sinai e Sion. De duobus montibus, Biblioteca Patristica 25, Firenze 1994, s. 178-179.

16 To lektura przyjmowana również w kręgach prawowiernych wspólnot. Zob. np. Hilarius Pictaviensis, Tractatus in Psalmum 64, 2.

17 Ps-Cyprianus, De duobus montibus 10.

18 Ściślej chodzi o Ap 12,2.10.12.14.16. 
i traktuje Syjon - Jerozolimę przede wszystkim jako miejsce męki i śmierci Zbawcy ${ }^{19}$. To obrazy wskazujące na opracowaną przez donatystów interpretację dosłowną narracji biblijnej w kontekście eklezjologicznym ${ }^{20}$. Rzecz jasna refleksja eklezjologiczna tego typu nie była wyłącznie owocem spekulacji donatystów ${ }^{21}$.

Przy omawianiu historii zbawienia autorzy chrześcijańscy zwracali uwagę na ,prymat miejsca" ukazany w świętych księgach i na tej podstawie formułowali zasadę teologiczną ,ś́więtości Jerozolimy"22. Donatyści byli szczególnie wyczuleni na kult relikwii z Palestyny ${ }^{23}$. Taka postawa znamionowała w zasadzie większość wiernych żyjących w basenie Morza Śródziemnego, na trenie rzymskiej Afryki ${ }^{24}$ czy w Azji Mniejszejej Zwyczaje te znalazły potwierdzenie archeologiczne ${ }^{26}$.

W ,geografii wiary” miasto święte stanowiło najważniejszy punkt. Donatyści jednak przywłaszczyli sobie tę koncepcję także w sferze symbolicznej. Poświadcza to mozaika z Castellum Tingitanum (obecnie El Asnam; ok. 324 rok). Przedstawia ona kwadratowy labirynt ${ }^{27}$, który ,zbiega się w centrum, utworzonym przez kwadrat, którego nazwę można odczytać we wszystkich kierunkach: Sancta Ecclesia [...]. (Kompozycja) wyraża schizmę, ograniczającą się do jednego zakątka ziemi, podczas gdy Kościół rozpościera się wszędzie, na całym świe-

19 Warto zwrócić uwagę na fakt, że przywołanie sceny męki Chrystusa tłumaczy znaczenie góry Syjon. W teologii donatystów śmierć Pana pomiędzy dwoma łotrami wskazuje na lud Kościoła i „naród o twardym karku” odrzucający zbawienie i prześladujący Kościół. Te aspekty określone są nie tylko w kontekście gór Synaju i Syjonu, ale również poszczególnych ludów.

20 Metafora góry Syjon łączy się z obrazem winnicy Pańskiej i Chrystusa wywyższonego na krzyżu pośrodku winnicy. Por. Ps-Cyprianus, De duobus montibus 14, 2.

21 Jej korzeni należy szukać w dziełach Cypriana. Z kolei numidyjski biskup Optat zestawia duchową górę Syjon z figurą Jerozolimy jako synonim jedynego i prawdziwego Kościoła. Zob. Optatus Afrus, De schismate donatistarum III 2, 7-8.

22 Cyrillus Hierosolymitanus, Catechesis XIII 28.

23 Św. Augustyn zauważył sarkastycznie, że czczą każde ziarnko pyłu pochodzącego z Ziemi Świętej. Por. Augustinus Hipponensis, Epistula 72, 2. Inny znany przykład pochodzi z De civitate Dei (XXII 8,6).

24 Potrafił to wykorzystać Ewodiusz di Uzali, który umieścił w odzyskanej dla katolików bazylice donatystów przywiezione z Jerozolimy relikwie św. Szczepana.

25 Paulin z Noli potwierdza praktykę przywożenia kamieni z miejsc świętych i sanktuariów Palestyny. Por. Paulinus Nolanus, Epistula 49, 14.

26 Por. B. Bagatti, Il Golgota e la croce, Jerusalem 1978, s. 53.

27 Na temat symboliki tego elementu, zob. D. Forstner, Świat symboliki chrześcijańskiej. Leksykon, Warszawa 2001, s. 63-64. 
cie" ${ }^{28}$. Kwadrat oznaczał trwałość ${ }^{29}$, a w pojęciu starożytnych ta figura geometryczna była symbolem świata ${ }^{30}$.

Akcentowanie warunków topograficznych stało się z czasem normą w opisach pielgrzymów i ważnym elementem egzegezy jako podstawa wprowadzenia wątków teologicznych i moralnych oraz łączenia konkretnych realiów geograficznych z symbolicznymi. Była to wspólna tradycja akcentowana przez niektórych autorów łacińskich, greckich i orientalnych ${ }^{31}$. U donatystów refleksje te przybrały bardzo specyficzny kierunek. Afryka miała być miejscem pojawienia się posłańca Bożego - Donata, co rzekomo przepowiedzieli prorocy. Schizmatycy uporczywie utożsamiali Donata $\mathrm{z}$ postacią określaną w tekście biblijnym jako Sanctus de monte ${ }^{32}$. Zwalczający przekonania donatystyczne sporo musieli się natrudzić, by zdyskredytować ten wątek. Schizmatycy bowiem pozwalali sobie na bardzo wiele w swojej uproszczonej interpretacji tekstów biblijnych ${ }^{33}$. W szczegółowszej analizie myśli polemistów antydonatystycznych jest to bardziej widoczne. Dla nich było oczywiste,

28 A.G. Hamman, Życie codzienne w Afryce Pólnocnej w czasach św. Augustyna, tt. M. Stafiej-Wróblewska - E. Sieradzińska, Warszawa 1989, s. 304. W kwestii archeologii i epigrafiki donatystycznej, por. Adamiak, Deo Laudes, s. 20-22.

29 W koncepcji Augustyna kwadrat był symbolem sprawiedliwości. Zob. Augustinus Hipponensis, De quantitate animae IX 10.

30 W oparciu o tekst Iz 11,12 mówiono o „forma quadrata mundi”. por. Ps.Hieronymus, Expositio Evangelii secundum Marcum 15. Taka była również koncepcja kosmologiczna Kosmasa Indikopleustesa (por. Topographia christiana IV 8).

31 Zob. M.C. Paczkowski, Zbawienie i jego geograficzny wymiar w patrystycznej interpretacji Ps 74(73),12, BPTh 11/1 (2018) s. 49-51. Elementy geograficzne posłużyły Atanazemu z Aleksandrii, by rozwinąć ideę powołania do Kościoła ludów pogańskich. Zob. Athanasius Alexandrinus, In Psalmum 47, 3. Teodoret z Cyru przedstawiał Jerozolimę na tle geografii biblijnej i ludów zamieszkujących sąsiednie regiony. Por. Theodoretus Cyrensis, Interpretatio in Psalmum 59, 10; 88, 13; Theodoretus Cyrensis, Interpretatio in Jeremiam I 1, 12; Theodoretus Cyrensis, Interpretatio in Ezechielem VIII 21, 1-2; Theodoretus Cyrensis, Interpretatio in Abdiam 19. Poeta syryjski Kyrillonas tak oto opiewał tamtejsze rejony: „Południe [o Zbawco] jest wypełnione Twoimi czynami i faktami, które wiążą się z Tobą: Twoim poczęciem, narodzeniem, ukrzyżowaniem, miłym zapachem Twoich kroków". Cyrillonas, Carmen VI 312.

32 Ojcowie Kościoła podkreślali, że „górami” nazywano wielkich ewangelizatorów i apostołów. Por. Augustinus Hipponensis, Sermo 46, 24). Warto dodać, iż wśród autorów greckich Teodoret z Cyru utożsamiał góry wspomniane w ST z prorokami, apostołami i aniołami strzegącymi wiernych. Zob. Theodoretus Cyrensis, Interpretatio in Psalmum 47, 3.

33 Donatyści twierdzili, że „świadectwa [biblijne] są niejasne, a wyjaśnione w sensie metaforycznym, pozwalają na inne ich rozumienie, chociaż ja, na tyle, na ile mogłem, 
że Donata nie należy identyfikować z „górą Pańską" ${ }^{34}$, a Kościoła donatystycznego $-\mathrm{z}$ Syjonem. Według schizmatyków to właśnie stamtąd zostali wyłączeni traditores. Wśród autorów prawowiernych powszechne było jednak przekonanie, że chwała Syjonu przechodzi na Kościół, a wzmianki o tym wzniesieniu mają na celu ukazanie jego wielkości w znaczeniu duchowym ${ }^{35}$. Południe, gdzie sytuowano Jerozolime, to według donatystów miejsce, gdzie był obecny „Kościół świętych”, eschatologiczna wspólnota wiernych. To azyl dla tych, którzy nie przyłączyli się do „wielkiego odstępstwa" ${ }^{36}$. Należy dodać, że szczegóły topograficzne związane ze świętym miastem stanowiły przedmiot dyskusji eklezjologicznych pomiędzy katolikami a donatystami także w innych rejonach świata (np. w Rzymie i w północnej Italii) ${ }^{37}$.

Interesujące ślady przekonań afrykańskiej sekty odkryto w tzw. capi$t_{u l a}{ }^{38}$. Według tekstu kwalifikowanego jako donatystyczny np. perykopa Iz 52,6-11 odnosi się do Jerozolimy, ,czyli Kościoła, Chrystusa Pana i Jego świętych, a [ci właśnie] mają opuścić miasto grzechu"39. Ta interpretacja bazująca na znaczeniu eklezjalnym pozwala zrozumieć, co powodowało, że był to ważny tekst dla donatystów oraz jakie były powody, iż sięgał po niego np. Parmenian.

Schizmatycy afrykańscy do niektórych wersetów biblijnych odwoływali się częściej i z większym przekonaniem. Z tekstów NT w polemice antydonatystycznej wykorzystywano J 4,23-24. Przykład tego

starałem się, by nie ośmielali się tak mówić”. Augustinus Hipponensis, Epistula ad catholicos 10,25 .

34 Ten symbol przemawiał bardzo mocno do wyobraźni. Wspomnienie „góry Pana” pozwalało wznieść myśli i serce ku rzeczywistości pozaziemskiej i budziło uczucia spontanicznej religijności.

35 Cyryl Aleksandryjski pisał, że „do Syjonu położonego na górze podobny jest Kościół, czyli wielka liczba wiernych [...]. Kościół jest bowiem wywyższony i nie ma w sobie niczego, co byłoby przyziemne". Cyrillus Alexandrinus, In Psalmum 136, 1 (Syjon i Jerozolima to zapowiedzi Kościoła). Zob. Cyrillus Alexandrinus, In Isaiam I 1; 2 , 3 ; III $1 ; 28,1$.

36 Por. J.A. Hoover, The Donatist Church in an Apocalyptic Age, Oxford Early Christian Studies, Oxford 2018, s. 155.

37 Polemika, którą rozwinął św. Augustyn, świadczy o żywej debacie na ten temat.

38 Capitulum to nie tylko urywek lub streszczenie fragmentu Pisma Świętego, ale czasami także komentarz czy wskazówka interpretacyjna. Ta forma nigdy nie była teologicznie neutralna, ale ukierunkowana na określoną doktrynę. Por. R. Niparko, Capitulum, EK II 1320.

39 Capitula 146-147 według J. Hoover, Decoding the Donatist Capitula, North American Patristics Society Conference, Chicago 2018, https://www.academia. edu/36497476/ Decoding_the_Donatist_Capitula (8.04.2019). 
typu stanowi anonimowa mowa $\mathrm{z}$ tzw. kolekcji wiedeńskiej (Sermones Escorial) ${ }^{40}$. Otwiera ją ekshortacja do podejmowania życia chrześcijańskiego ${ }^{41}$. Autor - donatysta dokonuje rozróżnienia pomiędzy „fałszywymi wierzącymi” (należącymi prawdopodobnie do Kościoła katolickiego) a prawdziwymi chrześcijanami (członkami grupy schizmatyckiej). Wyznawanie wiary donatystycznej jest równoznaczne $\mathrm{z}$ pójściem drogą prawdy ${ }^{42}$. W myśl perykopy Janowej autor odrzuca kult materialny w Jerozolimie, gdyż Boga należy czcić „w Duchu i prawdzie”. Czynią to, rzecz jasna, tylko donatyści prowadzący nienaganne pod względem moralnym życie. Za prawdziwy Kościół uważa się wspólnotę wybranych, posłusznych bezwarunkowo Bożemu Prawu ${ }^{43}$. Radykalizm donatystów nie pozostał bez odpowiedzi.

\section{Kierunki refleksji Optata z Milewy i Tykoniusza}

Ze świadectw epoki wynika, że to Optat z Milewy jako pierwszy rozpoczął polemikę $\mathrm{z}$ dziełem napisanym przez schizmatyka donatystę Parmeniana ${ }^{44}$. Numidyjski biskup stanął przed wyzwaniem, by poruszyć różnorodne problemy natury historycznej i religijnej ${ }^{45}$. Optat z Milewy w interpretacji Pisma Świętego nawiązywał do eklezjologii i aktualizował je, nawiązując do sytuacji wiernych w Afryce rzymskiej IV wieku. Natchnione teksty ukazywały tajemnicę Kościoła, jednak dla donatystów była to rzeczywistość obecnego czasu, a dla katolików dotyczyła

40 Na temat tych homilii, zob. J.L. Grabau, John 4:23-24 in North African Preaching, „Scrinium” 13 (2017) s. 138-140.

41 W okresie odrodzenia autorstwo tej mowy przypisywano Janowi Chryzostomowi.

Por. Grabau, John 4:23-24, s. 138.

42 Sermo Escorial 16.

43 Por. Sermo Escorial 16.

44 Pochodził z Galli lub Hiszpanii, był wykształconym mówcą i sprawnym administratorem. Jako donatystyczny biskup Kartaginy prężnie działał przez ponad trzy dekady i był tolerowany przez władzę świecką. Z powodzeniem krzewił idee swojej sekty, która dzięki niemu zyskiwała wielką popularność, Zob. D. Budzanowska-Weglenda, Tykoniusz i jego reguły egzegezy biblijnej. Monografia literacka, Warszawa 2015, s. 79.

45 Parmenian i Optat to najlepsi polemiści w tej kwestii na terenie Afryki Rzymskiej. Augustyn mógł później przedstawić szczegółową dokumentację spornych wydarzeń, by umożliwić swoim słuchaczom świadomy wybór drogi prawdy, a następnie wyjaśniał tajemnicę Kościoła. Por. T. Kaczmarek, Augustyn - Ekumenista, SWł 15 (2013) s. 29. 
ona już etapu eschatologicznego w doskonałości Kościoła ${ }^{46}$ - Jerozolimy i Oblubienicy Boga (por. Pnp 6,8 $)^{47}$.

Polemiści antydonatystyczni zauważali, że ich oponenci w biblijnych opisach odnoszących się do Jerozolimy i Syjonu odnajdywali drogę, którą powinni kroczyć jako żyjący na świecie. Z kolei Optat z Milewy postrzegał w nich zapowiedź przyszłej doskonałości Kościoła w niebiosach ${ }^{48}$. U tego katolickiego egzegety jest zaskakujące to, że wykazuje on dobrą znajomość topografii stolicy Ziemi Obiecanej ${ }^{49}$. Swój wywód oparł na Iz 2,3.

Nie słyszałem, aby w tym miejscu narodził się jakiś spór. Nie sprawowano tam także sądu i żaden z sędziów nie wydał tam wyroku, gdyż było to miejsce przeznaczone do przepowiadania doktryny, a nie do wzbudzania sporów po przedstawieniu nauki. Jeśli należało działać, to tylko w obrębie murów Jerozolimy $^{50}$. Z tego powodu napisano u proroka Izajasza: „Prawo wyjdzie z Syjonu i słowo Pańskie - z Jeruzalem” (Iz 2,3). Izajasz nie dostrzegł więc w owej dolinie góry Syjonu, ale „na górze”, którą jest Kościół. Góra ta wznosi swój wierzchołek nad całym światem rzymskim, pod każdą rozpiętością nieba. Syn Boży upodobał go sobie na miejsce królowania danego Mu przez Boga Ojca, jak mówi Psalm: „Ja ustanowiłem sobie króla na Syjonie, świętej górze mojej" (Ps 2,6) [...]. Duchową Jerozolimą jest Kościół, w którym Chrystus został ustanowiony Królem przez Boga Ojca. [Kościół] rozprzestrzenił się na cały świat i na całym świecie istnieje wyłącznie jeden Kościół katolicki. Syjon to prawdziwy Kościół ${ }^{51}$.

46 Por. Tilley, The Bible in Christian North Africa, s. 309-310.

47 Pieśń nad Pieśniami stanowiła centrum refleksji eklezjologicznej donatystów i katolików. Na temat perykop z tej księgi dyskutowali Parmenian, Optat z Milewy i św. Augustyn. Por. M. Cameron, Augustine's Use of the Song of Songs against the Donatists, w: Augustine Biblical Exegete, ed. F. van Fleteren - J.C. Schnaubelt, New York 2001, s. 99-127.

$48 \mathrm{Na}$ temat metafor stosowanych przez Optata w polemice antydonatystycznej, por. C. Mazzucco, La pace come unità della Chiesa e le sue metafore in Ottato di Milevi, CCC 12 (1991) s. 173-211.

49 Rozróżnia poszczególne części Jerozolimy, chociaż nie czyni tego na podstawie bezpośredniego doświadczenia, lecz opierając się na relacjach z drugiej ręki. O tym, że takowe istniały, świadczy Itinerarium Burdigalense. W tym dokumencie opis Optata znajduje pełne potwierdzenie: „Z siedmiu synagog, które tam były [na Syjonie], pozostała tylko jedna, pozostałe zostały zaorane i zamienione w pole, jak rzekł prorok Izajasz (por. Iz 1,8)". Itinerarium Burdigalense 592.

50 Itinerarium Burdigalense sugeruje, że Syjon znajdował się poza obrębem właściwego miasta. Por. Itinerarium Burdigalense 393.

51 Optatus Afrus, De schismate donatistarum III 2, 6-7. Na temat pism tego autora, por. Adamiak, Deo Laudes, s. 10-13. 
Optat wzorował się prawdopodobnie na interpretacji Cypriana z Kartaginy ${ }^{52}$ i anonimowym dziele De duobus montibus ${ }^{53}$. Numidyjski biskup cytuje te same wersety biblijne i używa tej samej terminologii, co utożsamiany z samym Cyprianem anonimowy autor ${ }^{54}$. Wskazuje to na fakt, że Iz 2,3 i Ps 2,6 stanowiły kluczowe wersety w polemice antydonatystycznej ${ }^{55}$. Optat dodaje, że Chrystus jest „Królem, Oblubieńcem i Głową” Kościoła przedstawionego jako wzniesienie Syjonu (in monte Sion [...] qui est Ecclesia) ${ }^{56}$. Zaraz potem wyjaśnia: „Nie chodzi tu o górę materialną [...], [gdzie] po zwycięstwach Wespazjana pozostają zaledwie tylko ślady starożytnych ruin. Duchowym Syjonem jest [...] Kościół [...], który rozciąga się po całym świecie" ${ }^{57}$. Z kolei w wizji prorockiej „doliny góry Syjonu” chodzi o rejon Afryki. „Tam tylko, gdzie w wystarczającej liczbie istniały już Boże świątynie, wasi przywódcy [donatystów] zechcieli zbudować inne; tam tylko zburzono mury, woda świętej sadzawki zmieniła kierunek; przez was nowość wprowadzono wbrew tradycji, woda ludzka została przeciwstawiona Bożej wodzie"s8.

Jesteśmy w samym centrum polemiki antydonatystycznej wskazującej na kluczową kwestię chrztu. Eklezjologia schodzi niejako na drugi plan, gdy pojawia się okazja, by polemizować z donatystyczną wizją ,sakramentu odrodzenia"59. Sadzawka opisana w Iz 22,9 była ,święta", lecz poprzez praktykę powtórnego chrztu (rebaptisma) donatyści napełnili ją wodą wyłącznie ludzką. Katolicki biskup Milewy przygotował grunt dla Augustyna ${ }^{60}$, który dzięki jego refleksji mógł skuteczniej zbijać argumenty donatystów ${ }^{61}$.

52 Por. opinię M. Lambrousse'a w: SCh 413, s. 15. Cyprian interpretuje Iz 54,1-3, mówiąc o Kościele, który najpierw był bezpłodny, lecz teraz ma więcej dzieci z pogan, aniżeli miała wcześniej synagoga. Por. Cyprianus, Testimonia ad Quirinum I 20.

$53 \mathrm{Na}$ stronicach tego ostatniego pisma występuje podobna interpretacja typologii „góry Syjon”.

54 Por. Ps-Cyprianus, De duobus montibus 3.

55 Por. E. Romero-Pose, El tratado ,de montibus Sina et Sion” y el donatismo, „Gregorianum” 63 (1982) s. 276. Warto zauważyć, że w swoim opracowaniu ten badacz hiszpański jako pierwszy podkreślił związek eklezjologii donatystycznej z tekstem pseudo-Cypriana.

56 Optatus Afrus, De schismate donatistarum III 2, 7.

57 Optatus Afrus, De schismate donatistarum III 2, 8.

58 Por. Optatus Afrus, De schismate donatistarum III 2, 9.

59 Rozważanie podsumowuje Iz 22,9-11.

60 Na temat wpływów Optata z Milewy na Hippończyka, por. C. Mazzucco, Ottato di Milevi in un secolo di studi: problemi e prospettive, Università degli studi di Torino. Dipartimento di filologia, linguistica e tradizione classica 3, Bologna 1993, s. 133.

${ }^{61}$ Augustyn napisał dziewięć dzieł związanych z polemiką z donatystami. Pisał również do donatystów, jak chociażby do biskupa Januarego czy do Parmeniana w obro- 
Z kolei Tykoniusz ${ }^{62}$ ujawnił słabe punkty w donatystycznej eklezjologii. Ten świecki teolog, przeniknięty ideami donatystycznymi, pojawił się w IV wieku w Afryce Północnej. Chociaż został potępiony przez afrykańską sektę, starał się dostosować eklezjologię donatystów do zmieniających się warunków historycznych ${ }^{63}$. W swoim najważniejszym dziele, czyli we fragmentarycznie zachowanym Komentarzu do Apokalipsy ${ }^{64}$, Tykoniusz rezygnował z wszelkich prób ustalenia konkretnego czasu wydarzeń ostatecznych. Warto podkreślić, że swoją sławę egzegeta-donatysta zawdzięczał w dużej mierze św. Augustynowi i jego autorytetowi ${ }^{65}$. Hippończyk miał na uwadze przede wszystkim reguły egzegetyczne Tykoniusza ${ }^{66}$, a także cenił go jako teologa, nigdzie nie wskazując na jakiekolwiek błędy natury dogmatycznej ${ }^{67}$.

Tykoniusz w oparciu o tekst ostatniej księgi NT mówił o Kościele jako świątyni $\mathrm{w}$ niebie ${ }^{68} \mathrm{i}$ oblubienicy Baranka ${ }^{69}$. Są to określenia stawiane na równi z metaforą Syjonu/Jerozolimy jako Kościoła ${ }^{70}$. Niejednokrotnie jednak ten egzegeta odchodził praktycznie od typowej lektury eschatologicznej Apokalipsy, wyjaśniając jej treść jako odnoszącą się przede wszystkim

nie Tykoniusza. Zob. Index opusculorum S. Augustini contra donatistas, PL 43, 757-760. Nie brak ponadto licznych okazjonalnych wypowiedzi, odniesień w korespondencji i przy wyjaśnianiu psalmów. Niektóre dzieła antydonatystyczne hippończyka zaginęły. Por. B. Altaner - A. Stuiber, Patrologia, Warszawa 1990, s. 558. Zob. wykaz w: Adamiak, Deo Laudes, s. 13-15.

62 Informacje dotyczące jego życia można odnaleźć w De viris inlustribus Gennadiusza z Marsylii - rozdz. 18 (TU 14 A, s. 68-69).

63 Zob. S. Adamiak, Eklezjologiczny charakter Komentarza do Apokalipsy donatysty Tykoniusza, BPTh 5 (2012) s. 151-162.

64 Augustyn znał i wykorzystywał to dzieło. Ponadto czerpali z niego Prymazjusz, Cezary, Beda Wielebny i Beatus z Liebany. Por. M. Simonetti, Między dosłownościa a alegoria. Przyczynek do historii egzegezy patrystycznej, tł. T. Skibiński, Kraków 2000, s. 297.

65 Opracowania poświęcone Tykoniuszowi są związane ściśle z refleksją nad myślami i spuścizną Augustyna.

66 Są one ,jakby kluczami, dzięki którym można otworzyć tajemnice Pisma Świętego". Augustinus Hipponensis, De doctrina christiana III 30, 42.

${ }_{67}$ W kwestiach eklezjologii uznawał go nawet za pisarza ortodoksyjnego. Por.

B. Czyżewski, Ocena Liber regularum Tykoniusza przez św. Augustyna, „Studia Bydgoskie" 3 (2009) s. 246.

68 Tichonius Afer, Commentarius in Apocalypsis ad 15, 6.

69 Tichonius Afer, Commentarius in Apocalypsis ad 19,7.

70 Należy dodać, że typologia występująca w tykoniańskim Liber Regularum powraca często w egzegezie Augustyna o Psalmach i w Mowach. Nakreślony tam wizerunek Jerozolimy przyjmuje nierzadko rysy nakreślone przez Tykoniusza. 
do teraźniejszego życia Kościoła ${ }^{71}$. Posunął się nawet do ogólnego wniosku, że Apokalipsa nie opisuje niczego poza Kościołem ${ }^{72}$. W tym punkcie przychylał się niebezpiecznie w stronę donatystów, którzy uważali siebie za „Kościół prześladowany”, opisany w NT. Wybrzmiewało w jego komentarzu nawiązanie do sytuacji współczesnej, tak więc nie chodziło o minione prześladowania chrześcijan, lecz o konflikt między katolikami i donatystami. Opisy cierpień i prób z Apokalipsy jego zdaniem odnosiły się więc po prostu do sytuacji w Afryce ${ }^{73}$.

Tykoniusz zdawał sobie sprawę $\mathrm{z}$ istnienia grzechu w członkach Kościoła $^{74}$. Egzegeta donatystyczny postrzegał nie tylko to, że Kościół musi się liczyć z rzeczywistością słabości moralnej, ale jednocześnie, że jest ona elementem obecnym w ziemskiej wspólnocie wiernych. Tykoniusz w regule II opisuje dokładniej członków Kościoła i wyjaśnia, że Pismo Święte mówi o nim jako o ciele dwojakim, składającym się z dwóch części: dobrych i złych ${ }^{75}$. Wizja Jerozolimy jako miasta, z jednej strony upadłego i poniżonego, a $\mathrm{z}$ drugiej oczekiwanie na jego chwałe i odbudowę, dawały okazję do tego typu refleksji. Te elementy były jednocześnie biblijnymi podstawami koncepcji permixta Ecclesia.

Tykoniusz utrzymywał, że Jerozolima jest dwojaka (Hierusalem bipertita est), a także jej bramy mają dwojaki sens. „Swięte bramy” miasta Jerozolimy według Tykoniusza stanowi osoba Chrystusa. Ci, którzy wchodzą przez Niego, wkraczają do wiecznej Jerozolimy. Przez bramę dolnego miasta wychodzi się ze świętego Jeruzalem i wchodzi się przez nie „na przeklęte miejsca". Wchodzący niewłaściwą bramą są złodziejami i fałszywymi apostołami ${ }^{76}$.

71 Augustyn również był przekonany, że „rachmistrzom [czasów eschatologicznych] rozwiązuje ręce i zamyka usta Ten, co powiedział: «Nie wasza rzecz wiedzieć czasy, które Ojciec w swej władzy położył»” (Augustinus Hipponensis, De civitate Dei XVIII 53).

72 Zob. Tichonius Afer, Commentarius in Apocalypsis ad 7, 11. Obraz Kościoła wyłaniający się z tego komentarza jest bliższy poglądom katolickim niż doktrynie donatystycznej.

73 Na przykładzie Łk 17,29-32 Tykoniusz pokazał, że wskazania dotyczące przyszłych wydarzeń należy stosować w teraźniejszości. Por. Budzanowska, O rekapitulacji wedtug Tykoniusza, s. 84.

74 Donatystyczna koncepcja mówiła o radykalnej separacji „świętych” od świata. To państwo Boże - Kościół (Ecclesia sanctorum) broniący się przed miastem diabła, czyli światem i fałszywymi chrześcijanami. Nic więc dziwnego, że „mury duchowe” i materialna separacja miały chronić dobrych chrześcijan od atakujących ich obywateli „miasta szatana”.

75 Por. Simonetti, Między dosłownościa a alegoria, s. 298.

76 Por. Tichonius Afer, Liber regularum V 14. Tykoniusz przywołuje teksty Mt 16,19; 23,13.37. Zob. Budzanowska-Weglenda, Tykoniusz i jego reguły egzegezy biblijnej, s. 280-282. 
Antagonizm pomiędzy „miastem Bożym” a „miastem szatańskim” wszedł w zakres klasycznych antytez, których kluczowym elementem jest Jerozolima. Pojawił się on nie tylko u Tykoniusza ${ }^{77}$, torując sobie drogę w tradycji chrześcijańskiej. Początkowo cesarstwo rzymskie, jako prześladujące uczniów Chrystusa, było utożsamiane z miastem szatańskim. Dla donatystów to Kościół stanowił miasto Boże, ale $\mathrm{z}$ wyłączeniem traditores, czyli w praktyce w jego skład wchodziliby wyłącznie przedstawiciele schizmatyków.

Tykoniusz sięgnął do Apokalipsy, by rozwinąc rozważania na temat „dwudzielności” Kościoła, które wydają się bezpośrednią inspiracją dla antytezy dwóch miast biblijnych: Jerozolimy i Babilonii ${ }^{78} \mathrm{~W}$ refleksji św. Augustyna ${ }^{79}$. Chodziło jednak nie tylko o polemiczne przeciwstawienie idei Kościoła katolickiego i sekciarskiej wspólnoty ${ }^{80}$, ale o konfrontację dwóch rzeczywistości w nich obecnych - dobra i zła grzechu oraz niemożność oddzielenia świętych od grzeszników przed końcem świata ${ }^{81}$. Przechodzenie od jednej obediencji do drugiej w Kościele afrykańskim podzielonym przez donatystów prowadziło do wyraźnego rozróżniania między teologicznym wymiarem Kościoła jako rzeczywistości zbawczej i Kościoła w jego codziennym doświadczeniu.

Eklezjologia tykoniańska nie była próbą poszerzenia ram Kościoła do tego stopnia, aby dać w nim miejsce każdemu rodzajowi zła, na co wskazuje Reguła VII ${ }^{82}$. Pokazany zostaje bowiem szatan i klęska jego

77 Por. A. Quacquarelli, La concezione della storia nei Padri prima di S. Agostino, Roma 1955, s. 123-137.

78 Na temat rozwoju tej idei u św. Augustyna, por. A. Lauras, Deux cites, Jérusalem et Babylone. Formation et évolution d'un thème central du „,De Civitate Dei”, „La Ciudad de Dios. Revista Augustiniana de cultura e investigación" 167/1 (1954) s. 117-150. Ponadto por. J. van Oort, Jerusalem and Babylon. A Study into Augustine's City of God and the Sources of his Doctrine of the Two Cities, Leiden 1991. Zob. również A. Lauras $\mathrm{H}$. Rondet, Le thème des deux cités dans l'oeuvre de saint Augustin, Études Augustinienes, Paris 1953, s. 99-160. A. Lauras w opracowaniu poświęconym antytezie konkluduje, że jest to rezultat osobistej interpretacji Augustyna (por. Deux cités, przede wszystkim na s. 118, przyp. 4). Także van Oort przychyla się do tej opinii. Por. van Oort, Jerusalem and Babylon, s. 118.

79 Ten obraz wypełnia kazania hippończyka w czasie całego episkopatu i znajduje w końcu kres w De civitate Dei. Por. Czyżewski, Ocena Liber regularum Tykoniusza, S. 240.

80 Hippończyk trzymał się wątku dwóch miast w kluczowych punktach polemiki z donatystami (Contra epistulam Parmeniani II 4) i przeciwko Faustusowi (Contra Faustum XII 36; XX 21).

81 Por. A. Clerici, Sant'Agostino. La Chiesa da Eva alla città di Dio, Roma 2000, s. 22.

82 Brzmi ona: De diabolo et eius corpore. Zob. Tichonius Afer, Liber regularum prologus 3 . 
działania na świecie ${ }^{83}$. Swoją uwagę autor Liber regularum skupia na symbolice gór w kontekście ST. Tykoniusz przypomina, że „górą Bożą” jest wzniesienie Syjonu. To na nim oraz na górach Izraela i na swoich świętych obłokach, a tym właśnie jest Kościół, Bóg ma swój tron czy też siedzibę ${ }^{84}$. Góra diabła jest zupełnie inną górą niż Syjon - Kościół. To Seir (por. Rdz $14,6)^{85}$ należący do „braci zła" ${ }^{\prime 6}$. Tykoniusz podejmuje kwestię związaną z „Akwilonem”, czyli północą. Ten kierunek świata wiąże się z grzeszną częścią Kościoła. Z kolei „Austra”, czyli południe, oznacza dobrą jego cząstkę $^{87}$. Tykoniusz wskazywał, że w części południowej (dobrej) przebywa Pan, o czym świadczy samo Pismo Święte (por. Pnp 1,6). Do północy odnoszą się słowa J1 2,2088. Egzegeta afrykański nie zawsze był przykładem jasności wywodu, ale w tym przypadku antyteza bazująca na kierunkach świata północ-południe jest wyrazista i konsekwentnie stosowana.

Dla autora Liber regularum wydarzenia zapowiedziane przez proroka Daniela ${ }^{89}$ toczyły się w wówczas w Afryce. Tykoniusz nie używa dosłownych sformułowań tekstu prorockiego, zapewne zakładając u czytelnika ich znajomośćc ${ }^{0}$. Bez wątpienia autor miał w tych słowach na myśli rozdarcie w Kościele między katolikami i donatystami.

83 Por. W. Linke, Tykoniusz i jego komentarz do Apokalipsy, w: Pierwsze łacińskie komentarze do Apokalipsy: Hipolit, Wiktoryn, Hieronim, Tykoniusz, red. D. Budzanowska - W. Linke, Warszawa 2011, s. 174-175.

84 Tichonius Afer, Liber regularum VII 5. Tykoniusz cytuje Ps 32,8 (LXX); Za 2,13; Iz 5,6; Ps 96,2 (LXX).

85 Euzebiusz z Cezarei identyfikował Seir z Edomem i Idumeą. Zob. Eusebius Caesarensis, Onomasticon 150, 23-152,3; P.A. Kaswalder, Onomastica biblica. Fonti scritte e ricerca archeologica, Collectio Minor 40, Jerusalem 2002, s. 71, przyp. 111.

86 Tichonius Afer, Liber regularum VII 5. Egzegeta odwołuje się do Ez 35,14 i Iz 14,14 .

87 Teodoret z Cyru mówił o usytuowaniu Jerozolimy względem kierunków świata. Miasto święte znajduje się na południu. Z północy przybywa zło (por. Jr 1,14), lecz góry chronią Jerozolimę przed niebezpieczeństwem. Por. Theodoretus Cyrensis, Interpretatio in Psalmum 125, 4.

88 Por. Tichonius Afer, Liber regularum VII 6; Budzanowska-Weglenda, Tykoniusz i jego reguty egzegezy biblijnej, s. 116-118.

89 Zapowiedź prorocka dotyczyła pojawienia się w miejscu świętym „ohydy spustoszenia”. Por. Dn 8,$11 ; 9,27 ; 11,31$. O „ohydzie spustoszenia” lub „zgubnej nieprawości” wspomina 1Mch 1,54; Mt 24,15; Mk 13,14.

90 W opinii Hieronima chodziło o antychrysta, który „przywłaszczy sobie cześć Bogu należną [...]. Nazwany jest ohydą spustoszenia, ponieważ spustoszy ziemię przez zbrodnicze wojny i rzezie [...]. Stanie na miejscu świętym, aby tam, gdzie święci wznosili modły do Boga, został przyjęty przez niewierzących i odbierał cześć boską" (Hieronymus Stridonensis, Commentarii in evangelium Matthaei XXV 3). 
Tę sytuację opisuje za pomocą sformułowań z 2Tes 2,3: odstępstwo i objawienie się człowieka grzechu. W tej refleksji Tykoniusza widać, że przesłanie biblijne było dla niego bardzo aktualne. Wydarzenia zapowiedziane przez proroka miały toczyć się właśnie w Afryce, a nie „W czasie końca"91.

Do reguły rekapitulacji nawiązuje tykoniańska interpretacja fragmentu Księgi Psalmów ${ }^{92}$. Tykoniusz twierdził, że to członkowie Kościoła są jak poganie, których „niewolę Pan znosi”. Przeżywają oni taki sam czas, jak i ci ukazani w sposób metaforyczny w Ps 126,1-393.

Tykoniusz znajdował argumenty przeciwko donatystom również w otaczającym świecie. Według niego świat widzialny został stworzony na wzór Kościoła. Afrykański autor wskazuje więc na metaforyczne znaczenie wędrówki słońca po nieboskłonie. Jest ono przecież symbolem Chrystusa. Metafory ukierunkowane eklezjalnie stały się nie tylko kluczem interpretacyjnym tekstu, ale także służyły ocenie konkretnych wydarzeń, sytuacji historycznych i warunków geograficznych. Tykoniusz wypowiedział się w duchu bardzo katolickim, gdy wskazywał na jedność i powszechność nauczania Ewangelii: „Kościół nauczać będzie nie tylko jeden naród w Afryce, ale cały świat [...]. Na całym świecie jest jeden Kościół, dlatego też jego nauczanie jest to samo w Afryce i na całym świecie; dlatego też, kiedy Chrystus mówiąc: «Trzeba ci nauczać od nowa», zwraca się jakby specjalnie do Kościoła afrykańskiego" "94. Nawet przyjmując tezę, że Tykoniusz został „ukatolicyzowany", niektóre jego przekonania zachowały wyraźne konotacje antydonatystyczne.

Z refleksji Tykoniusza i Optata wynika, że istniała ugruntowana egzegeza donatystyczna niektórych fragmentów biblijnych. Wraz ze św. Augustynem mieli oni obaj do dyspozycji tych samych autorów co donatyści. Z tych zasobów wielki geniusz, jakim był biskup Hippony, potrafił umiejętnie korzystać ${ }^{95}$. Odwoływał się do tez obecnych i popularnych w kręgach teologów chrześcijańskich. Nie byli to wyłącznie autorzy pra-

91 Tichonius Afer, Liber regularum VI 3. To jedyna w tym dziele wzmianka o Afryce.

92 „Gdy Pan zniósł niewolę Syjonu [...], wtedy będą mówić między poganami: «Wielkodusznie postąpił z nimi Pan, wielkodusznie postąpił Pan z nami, staliśmy się radośni»" (Ps 126,1.3).

93 Zob. Tichonius Afer, Liber regularum VI, 3.

94 Tichonius Afer, Commentarius in Apocalypsis ad 10, 11.

95 Kontakt z przekonaniami Tykoniusza dał Augustynowi możliwość opracowania odpowiedzi na tezy donatystów, gdy konflikt z tą sektą zaostrzał się na płaszczyźnie doktrynalnej. Por. Hamman, Życie codzienne w Afryce Północnej w czasach św. Augustyna, s. 311. 
wowierni, ale w swoisty sposób do refleksji eklezjologicznej prowokowali mocno osadzeni w Afryce Rzymskiej donatyści ${ }^{96}$.

\section{Augustyn a typologia biblijnej Jerozolimy w kontekście eklezjalnym}

Stały punkt odniesienia łacińskiej tradycji teologicznej stanowi eklezjologia wypracowana przez św. Augustyna ${ }^{97}$. Należy przypomnieć, że traktował on Pismo Święte jako główne źródło w przepowiadaniu i w refleksjach teologicznych. W polemice z donatystami hippończyk wyrażał przekonanie, że ich doktryna nie ma w gruncie rzeczy podstawy biblijnej ${ }^{98}$. Nie obserwuje się więc na szeroką skalę w jego polemikach tak popularnego u Ojców Kościoła zabiegu, by proponować alternatywną interpretację spornych wersetów biblijnych. Egzegeza była więc swego rodzaju wartością dodaną. Hippończyk raczej selekcjonuje i przywołuje wielokrotnie wersety zaprzeczające twierdzeniom afrykańskich heretyków. W ujęciu autora De civitate Dei fakty ze ST przedstawiają to, co „było jedynie obrazem (por. 1 Kor 10,6) [...]. Dokonało się na starożytnych, obecnie to samo dzieje się z nami"'99.

Pismo Święte sugerowało nie tylko nazewnictwo, etymologię i kierunki interpretacyjne, lecz również treść teologiczną opisywanych przez hippończyka zjawisk i wydarzeń. To właśnie tego typu znaczenie najwydatniej odcisnęło swoje piętno w refleksji eklezjologicznej i na antytezie Jerozolima - Babilonia. Autor De civitate Dei przywoływał tę antytezę tylko wtedy, gdy pozwala na to tekst biblijny lub aluzja do niektórych faktów historii zbawienia ${ }^{100}$. Nierzadko jednak ma się nieodparte wrażenie, iż Doctor gratiae wręcz szuka okazji, aby rozpocząć dywagacje

96 Ostatecznie donatyzm zniknął dopiero po najeździe Arabów na Afrykę Północną. Por. Budzanowska-Weglenda, Tykoniusz i jego reguly egzegezy biblijnej, s. 79, przyp. 12.

97 Na temat eklezjologii wielkiego hippończyka, por. A. Lombardi, L'ecclesiologia di S. Agostino nella polemica donatista, w: I conflitti religiosi nella scena publica, ed. L. Alici, Roma 2015, s. 225-273.

98 Por. Augustinus Hipponensis, Epistula ad catholicos 16, 40.

99 Augustinus Hipponensis, Enarrationes in Psalmos 148, 5. Św. Augustyn ukazuje wizję zniewolenia i wyzwolenia, zniszczenia i odbudowy Jerozolimy. Zob. A. Clerici, Sant'Agostino. La Chiesa da Eva alla città di Dio, Roma 2000, s. 22.

100 Por. Tabula chronologica, w: CCL 38, s. XV. Antyteza Jerozolima - Babilonia występuje często w komentarzach do niektórych innych psalmów. Por. Enarrationes 
o Jerozolimie i Babilonii ${ }^{101}$. Biskup Hippony przywołuje również osobisty punkt widzenia, ubogacony przez wcześniejsze tradycje $\mathrm{e}^{102}$.

W tej kwestii interpretacja Augustyńska nie różni się zasadniczo od poglądów większości pisarzy chrześcijańskich ujmujących w podobny sposób dzieje narodu izraelskiego. Augustyn jednak wpisuje najdrobniejsze szczegóły historii świętego miasta w dzieje całego Kościoła. Podstawą tego punktu widzenia jest świadomość wyjątkowości historii narodu wybranego, którą potwierdziło Nowe Przymierze ${ }^{103}$. Augustyn przypominał o faktach z dziejów Kościoła czasów apostolskich: w Jerozolimie powstał kult dla imienia Jezusa i tam zrodziła się pierwsza wspólnota ochrzczonych. Ze świętego miasta rozpoczęło się przepowiadanie Ewangelii, które rozszerzało się mimo trudności prześladowań ${ }^{104}$. Obraz Jerozolimy nieustannie przywoływał obietnice Boże i ich realizację w rzeczywistości Kościoła Bożego.

Augustyn w stosowaniu klasycznej metafory góry Syjon - Jerozolimy - Kościoła ${ }^{105}$ właściwie odwrócił donatystyczny klucz interpretacyjny proroctw biblijnych. Przede wszystkim pozostawił nienaruszoną identyfikację ,góry” z Donatem, ale wykazywał niedorzeczność tego porównania. Czyni to na podstawie rozróżnienia dobrych i złych pagórków dla owiec - wiernego ludu Bożego ${ }^{106}$. Dochodziła do tego właściwa lektura proroc-

in Psalmos 26, 11, 18; 61, 6; 64; 86; 136; 138, 18; 145, 20; 147; Indeks w: NBA 28, s. 994 i 1046-1047.

101 Por. np. Augustinus Hipponensis, Enarrationes in Psalmos 9, 8. Ten temat pojawia się szczególnie często w jego pismach teologicznych i polemicznych, czego przykładem jest De catechizandis rudibus (zob. przede wszystkim XXI 37).

102 Dopatrzyć się można wpływów Orygenesa (In Jeremiam homiliae II 11; III 2; In Ezechielem homiliae XII 2), a także Ambrożego (De poenitentia II 11, 105-106; De fide III 1, 4; Explanatio Psalmorum 45, 16). Nie bez znaczenia były także komentarze Tykoniusza. Por. Tichonius Afer, Liber regularum IV. Zob. The Book of Rules of Tyconius, ed. F.C. Burkitt, Cambridge 1894, s. 50.

103 Z Izraela wywodzi się Chrystus wraz ze swoją Matką, a na łonie tego ludu rodzi się chrześcijaństwo, którego podstawę stanowili nawróceni Żydzi. Por. Augustinus Hipponensis, De civitate Dei XVII 16.

104 „Sam [Chrystus] powiedział, że pokuta winna być głoszona wszystkim narodom w Jego imieniu, lecz «począwszy od Jerozolimy» (por. Łk 24,47). Tam więc powstała cześć Jego imienia, aby wierzono w Jezusa Chrystusa, który został ukrzyżowany i zmartwychwstał" (Augustinus Hipponensis, De civitate Dei XVIII 54). Hippończyk nawiązuje do Iz 2,3.

105 Por. Augustinus Hipponensis, Contra Cresconium 2, 36, 45; Augustinus Hipponensis, Contra epistulam Parmeniani III 5, 28; Augustinus Hipponensis, Epistula 52, 1.

106 Por. Augustinus Hipponensis, Sermo 46, 16. Hippończyk komentował Ez 34,1-16 pomiędzy 408 a 410 rokiem. 
twa Ha 3,3, która według Augustyna polegała na identyfikacji południa (Africus $)^{107}$ jako Jerozolimy, z której Jezus wysłał na cały świat apostołów, aby głosili Dobrą Nowinę ${ }^{108}$. Donatyści z kolei uważali, co sarkastycznie podkreślił biskup Hippony, że „Chrystus stracił swój Kościół na całej ziemi i zaczął go mieć tylko u was. Dla naszej sprawy wystarczy spełnienie się proroctwa i zapowiedzi Pisma Świętego"109.

Dla wykazania słabych punktów egzegezy eklezjologicznej donatystów św. Augustyn przytacza całą serię tekstów biblijnych ${ }^{110}$, „aby nie błądzić odnośnie do Oblubieńca i Oblubienicy"111. Interpretacja ma charakter eklezjologiczny i chrystologiczny, ale w sensie bardzo szerokim, podkreśla bowiem i przyjmuje nierozerwalną jedność ciała i Głowy, Chrystusa i Kościoła ${ }^{112}$. Biskup Hippony przywoływał repertorium biblijne donatystów, by udowodnić, że ich doktryna nie miała podstaw w Piśmie Świętym ${ }^{113}$. Hippończyk podkreślał, że sam Chrystus wskazał na to, że nie należy pojmować Jerozolimy wyłącznie jako „miasta widzialnego". Jest ono bowiem ,symboliczne, [a] zawiera w sensie duchowym cały Kościół: ten wieczny w niebie i [jego] cząstkę, która pielgrzymuje na ziemi" ${ }^{114}$. Zarówno na jedno, jak i na drugie znaczenie miasta świętego wskazują słowa Chrystusa. „W znaczeniu rzeczywistym jest mowa o mieście, w którym wziął początek Kościół [...]. Zbawiciel nie zostawił przebiegłym heretykom najmniejszego miejsca, by mogli przeprowadzać swoje zasadzki"115.

Typologiczny wymiar Jerozolimy pozwala dostrzec civitas sancta i jej Władcę.

O kimże więc, jeśli nie o Nim, napisano te rzeczy, które i my cytowaliśmy z Prawa [Mojżeszowego], proroków i Psalmów [...]. Tak więc On, który jest

107 Africus to archaiczne określenie południa (meridie). Potwierdza to późniejsze tł. Wulgaty: Joz 15,8 i Ha 3,3. Por. Hoover, The Donatist Church, s. 157, przyp. 151.

108 Por. Augustinus Hipponensis, Sermo 46, 40.

109 Augustinus Hipponensis, Epistula 49, 3

110 Są to Ps 49,2; 56,5.6; Łk 24,44.46-47; J 14,6.

111 Augustinus Hipponensis, Epistula ad catholicos 10, 24.

112 Por. Simonetti, Między dostownościa a alegoria, s. 358. Hippończyk pojmował osobę Zbawiciela jako złączonego nierozerwalnie ze swoim Kościołem. Zob. Augustinus Hipponensis, De civitate Dei XVII 20.

113 Pod tym względem ten wielki Doktor Kościoła jest jak najbardziej godny zaufania.

114 Augustinus Hipponensis, Epistula ad catholicos 10, 26.

115 Augustinus Hipponensis, Epistula ad catholicos 10, 26. Hippończyk cytuje Łk 24,48-49 i krótko go wyjaśnia. 
Prawdą (por. J 14,6) mówi: „Musi się wypełnić wszystko”116, dlaczego donatyści temu zaprzeczają? Czyż nie dlatego, że są nieprzyjaciółmi prawdy? Jeśli potem upierają się, że teksty biblijne są niejasne, posłuchajmy także na ten temat Głowy [Chrystusa], który nam ukazuje w całej prawdzie swoje Ciało [Kościół] ${ }^{117}$.

Na bazie dziejów Kościoła apostolskiego Augustyn zwalcza ekskluzywizm donatystów. Według ich opinii zapowiedzi głoszenia Bożej prawdy wypełniły się, lecz narody odstąpiły od Chrystusa, a tylko pars Donati w Afryce pozostała przy Nim. Schizmatycy nie mówią jednoznacznie, czy „to ma się jeszcze stać czy już się dokonało. Jak więc to możliwe, że obwieszczono wiarę wszystkim narodom, a potem nastąpiło zatracenie [ich] wszystkich, oprócz Afryki" 118 .

Hippończyk przedstawił w jednoznaczny sposób znaczenie niektórych wyrażeń biblijnych ${ }^{119}$, które były kluczowe dla donatystów.

Wyjaśnij mi więc, co znaczą słowa: „Bóg przychodzi z południa” i „Święty z cienistej góry (Deus ab africo veniet, et Sanctus de monte umbroso)". Spójrz, jakie jest dla mnie łatwe wyjaśnienie. Posłuchaj najpierw słów Pana: Chrystus miał wszystko wycierpieć i zmartwychwstać trzeciego dnia, „w imię Jego głoszone będzie nawrócenie i odpuszczenie grzechów wszystkim narodom, począwszy od Jerozolimy" (Łk 24,47). Oto z której strony nadszedł Pan. Mówiąc, ,począwszy od Jerozolimy”, zapowiada, że stamtąd; a dzięki osobom swoich świętych dotarł do innych ludów. Przeczytaj w Księdze Jozuego, syna Nuna, w jaki sposób została podzielona pomiędzy pokolenia ziemia synów Izraela. Powiedziano tam jasno, że „na południe jest Jebuz, to jest Jerozolima" (por. Joz 15,8). Czytaj, badaj, a znajdziesz. Oby niebo zechciało, abyś po znalezieniu prawdy, uwierzył i przestał być [tak] zawziętym. „Na południe jest Jebuz, to jest Jerozolima” (por. Joz 15,8), a Pan [rzecze]: „Począwszy od Jerozolimy” (Łk 24,47) [...]. W jakim znaczeniu „,z cienistej góry"? Przeczytaj Ewangelię. Chrystus wstąpił do nieba z góry Oliwnej [...]. Czyż można jaśniej [określić]: ,z cienistej góry”"120.

Donatystyczny ekskluzywizm eklezjalny był więc zwalczany na płaszczyźnie biblijnej i topograficznej. W Liście do katolików ${ }^{121}$ pojęcie ,po-

116 Augustyn wielokrotnie przywołuje Łk 24,45-47.

117 Augustinus Hipponensis, Epistula ad catholicos 10, 24.

118 Augustinus Hipponensis, Epistula ad catholicos 17, 43.

119 Łacińskie tłumaczenie tekstu biblijnego często nie brało pod uwagę toponimów o drugorzędnym znaczeniu.

120 Augustinus Hipponensis, Sermo 46, 40.

121 List datowany na 401-402. 
łudnia” zostało wyeksponowane z podobną wyrazistością. W mentalności donatystów ta strona świata była interpretowana jako miejsce zgromadzenia eschatologicznego ludu Bożego. Augustyn jednak przypominał głównie o fundamentach Kościoła w Jerozolimie.

Jasno widać w Piśmie Świętym, że Kościół rozpoczyna się od Jerozolimy i aż do końca czasów rozwija się w innych narodach, póki nie posiądzie ich wszystkich; również nie mówi się tylko o dobrej pszenicy, ale także o jej zanieczyszczeniach chwastem, najpierw poprawcie się i zjednoczcie się z ziarnem, a później zobaczycie, co należy nazywać kąkolem i słomą ${ }^{122}$.

Oczywistą konstatację o Kościele apostolskim w świętym mieście odrzucali donatyści ${ }^{123}$. Ponadto według Augustyna utrzymywali, że na całym świecie rozrósł się kąkol, a czysta pszenica pozostała tylko w Afryce ${ }^{124}$. Schizmatycy byli przekonani również o trwałości swojej wspólnoty, powstałej z cennego i trwałego elementu ${ }^{125}$.

Donatyści mówili nieustannie o niedoskonałościach wspólnoty Kościoła powszechnego wynikających z ludzkiej skłonności do złego, na co Augustyn zwracał często uwagę. Wskazanie na tych, „którzy znienawidzili Jeruzalem, znienawidzili pokój, chcący rozerwać jedność [...], którzy wśród ludu głoszą fałszywy pokój i go nie posiadają" ${ }^{126}$, nie sprawiło jednak, że biskup Hippony pominął w dyskusjach przekonanie donatystów o wyjątkowości ich wspólnoty. Przypomniał więc fakt, że na terytorium Afryki Rzymskiej chrześcijaństwo pojawiło się dosyć późno ${ }^{127}$. Jednakże w porównaniu z rozległością świata ta jego część, gdzie rozprzestrzeniło się chrześcijaństwo, stanowiła zaledwie małą cząstkę ${ }^{128}$. Jednym

122 Augustinus Hipponensis, Epistula ad catholicos 18, 46.

123 Por. Augustinus Hipponensis, Epistula 185, 1. Zob. Hoover, The Donatist Church, s. 148.

124 Augustinus Hipponensis, Contra epistulam Parmeniani I 21.

125 Być może nawiązanie do 1Kor 3,10-12. Odnośnie do tego wątku, por. Origenes, Homiliae in Ezechielem XIII 3.

126 Augustinus Hipponensis, Enarrationes in Psalmos 124, 10. Kaznodzieja unikał czasami powtórzeń niektórych wątków odnoszących się do donatystów, obawiając się gwałtownych reakcji ze strony schizmatyckich słuchaczy. Por. D. Zagórski, Commendavit nobis Dominus oves suas. Pasterska troska o wiernych w świetle Sermones św. Augustyna, Toruń - Pelplin 2013, s. 168-169.

127 Por. Augustinus Hipponensis, Epistula ad catholicos 15, 37.

128 Tak św. Augustyn streszcza przekonanie jednego z biskupów schizmatyckich. Zob. Augustinus Hipponensis, Epistula 93, 7; Augustinus Hipponensis, Contra Cresconium 3, 70. 
z kontrargumentów był fakt, że Kościół rozszerzał się na barbarzyńców ${ }^{129}$. Dla większości jednak zapowiedź szerokiej ekspansji Kościoła realizowała się w ówczesnym świecie i na oczach wszystkich.

W wielu mowach Augustyna pulsuje żywe oczekiwanie wypełnienia się czasów eschatologicznych. Biskup Hippony jest jednak oszczędny w przywoływaniu obrazów apokaliptycznych i sądu ostatecznego. Być może chciał zachowywać dystans od sekt apokaliptycznych obecnych w Afryce. Jak się wydaje, tamtejsze przekonania eschatologiczne zakładały, że nawet Chrystus w chwale miał się objawić w Afryce. Augustyn mówił z sarkazmem o heretykach skłonnych utrzymywać, że Zbawiciel narodził się w ich ojczyźnie ${ }^{130}$.

Bardziej niebezpieczna od dziwacznych wyobrażeń wydawała się aktualizacja obrazów eschatologicznych głoszona w szeregach donatystów. Narzędzie walki z propagandą schizmatyków stanowiło ukazywanie eschatologicznej świętości Kościoła - Jerozolimy. Biskup Hippony ograniczał się jednak do podania tradycyjnej interpretacji wizerunku niebiańskiej Jerozolimy. Co więcej, w jednej ze swoich mów, wygłoszonych pomiędzy 393 a 395 rokiem, ujawnia się jego pozytywny stosunek do przekonań milenarystów ${ }^{131}$. W centrum wizji autora łacińskiego znajduje się jednak Kościół i zagadnienie odkupienia ${ }^{132}$. Augustyn twierdzi bowiem, że w „siódmym wieku świata" ${ }^{133}$ Kościół ukaże się jako chwalebna Jerozolima, w której zapanuje Pan i Jego święci ${ }^{134}$. Ta interpretacja wizji miasta niebiańskiego zniknie jednak bardzo szybko z kart pism biskupa Hippony, który wkrótce odżegnał się od niej, odrzucając otwarcie milenaryzm ${ }^{135}$. Obrazy apokaliptyczne Augustyn kwituje spostrzeżeniem, że ostatnia księga Biblii „powtarza te same rzeczy w tak różny sposób,

129 Por. Augustinus Hipponensis, Epistula 93, 7.

130 Por. Augustinus Hipponensis, Sermo 46, 38. Być może było to echo przeświadczenia montanistów o objawieniu się chwalebnego Jeruzalem w Azji Mniejszej, przeniesionym przez donatystów na teren Afryki. Na temat tej koncepcji, por. Epiphanius, Adversus haereses (Panarion) II 49, 1.

131 Chodzi tu o Sermo 259.

132 Por. G. Folliet, La typologie du „sabbat” chez saint Augustin. Son interprétation millénariste entre 389 et 400, REAug 2 (1956) s. 389.

133 Dla indywidualnego człowieka siódmym okresem jest życie wieczne, w którym nie istnieje czas ani historia. Ten stan jest stałym i trwałym celem człowieka duchowego. Por. E. Gilson, Wprowadzenie do nauki świętego Augustyna, Warszawa 1953, s. 227.

134 Augustinus Hipponensis, Sermo 259, 2.

135 Por. Augustinus Hipponensis, De civitate Dei XX 7. Tykoniusz w V regule sformułował teoretyczną podbudowę dla podważenia interpretacji millenarystycznej, proponując zasady metody alegorycznej w służbie egzegezy teologicznej. Por. Linke, Tykoniusz i jego komentarz do Apokalipsy, s. 174-175. 
iż wydaje się, że mówi o coraz to innych rzeczach, gdy tymczasem mówi o tym samym w inny sposób" ${ }^{136}$. Miejsce spekulacji na temat Ap 20-21137 zajmie obraz Jerozolimy duchowej. Opisy ostatniej księgi NT stają się okazją do uwydatnienia kwestii eklezjologicznych i chrystologicznych ${ }^{138}$. Przenikanie się rzeczywistości ziemskiej i duchowej to model interpretacyjny często spotykany w pismach augustiańskich ${ }^{139}$.

Zastanawia z kolei forma zdecydowanie polemiczna, w jaką autor De civitate Dei ubiera swoje argumenty w interpretacji Ap 21,4 $4^{140}$. Pozwala to przypuszczać, że istniała interpretacja aktualizująca ten werset apokaliptyczny, którą być może opracowali donatyści przypisujący swojej wspólnocie stan doskonałej świętości. Mogli to być również pelagianie głoszący doktrynę o samozbawieniu się człowieka dzięki własnym cnotom i mocy, bez konieczności łaski ${ }^{141}$. Hippończyk krytykuje negatywny wpływ zbyt liberalnej egzegezy Ap 21,4 prowadzącej do wypaczenia prawdy o słabości ludzkiej natury.

Odnośniki do uniwersalności Kościoła znajdują się w rozważaniach Augustyńskich o Księdze Psalmów. Wspomniany przez psalmistę „krąg Jeruzalem” (por. Ps 78,6) „sięga tam, dokąd rozprzestrzeniony był Kościół, przynoszący owoce i rozrastający się po całym świecie" ${ }^{142}$. Występując przeciwko donatystom, którzy zawężali rzeczywistość Kościoła do swojej sekty, biskup Hippony uwydatnia uniwersalizm proroctwa Izajasza zapraszającego wszystkie ludy do wstąpienia

136 Augustinus Hipponensis, De civitate Dei XX 17.

137 Opisy uzupełniał często tekst Ga 4,26. Interpretacja millenarystyczna Jerozolimy niebiańskiej będzie miała swoich zwolenników w średniowieczu, wśród ludowych ruchów religijnych i doktryn znajdujących się na marginesie oficjalnego nauczania Kościoła.

$138 \mathrm{~Np}$. Ap 21,12.21 w Enarrationes in Psalmos 86, 4. W oparciu o Ap 20,7-9 Augustyn wskazywał na „ostatnie prześladowanie”, które będzie cierpieć „całe państwo Chrystusa”. Przy tej okazji Augustyn zaznaczał, że „obóz świętych” i „miasto umiłowane" to nic innego, ,jak Kościół Chrystusowy, rozprzestrzeniony na całym świecie" (Augustinus Hipponensis, De civitate Dei XX 11).

139 Dzięki rozważaniom tego typu stało się łatwiejsze wprowadzenie zagadnień o charakterze teologiczno-duchowym. Tak więc „oglądanie” (etymologia Syjonu) oraz tematyka pokoju (etymologia Jerozolimy) stają się niejednokrotnie przedmiotem dłuższych refleksji.

${ }^{140}$ Przed Augustynem wielu autorów interpretowało ten werset w świetle przyszłej chwały życia wiecznego. Por. np. Tertullianus, De resurrectione 58, 3; Origenes, In Iesu Nave homiliae VIII 4; XX 1.

141 Widać to w komentarzu pelagiańskim do Listu do Rzymian. Por. T.S. De Bruyn, Pelagius's Commentary on St. Paul's Epistle to the Romans, Oxford Early Christian Studies 4, Oxford 1993.

142 Augustinus Hipponensis, Enarrationes in Psalmos 78, 6. 
do Jerozolimy, aby tam otrzymać słowo Pańskie. Jest to zapowiedź uniwersalizmu „wielkiego Kościoła” katolickiego. To właśnie rzeczywistość Kościoła zawiera w sobie każdy z aspektów konkretnego urzeczywistnienia się proroctw $^{143}$, chociaż istnieje w tym względzie dystans odnośnie do czasów odnowy eschatologicznej. Podczas gdy tradycja wschodnia widziała realizację proroctw w strukturze imperium i w osobach władców strzegących Kościoła, myśl chrześcijaństwa zachodniego, której Augustyn jest wyrazicielem, upatrywała w Kościele realizację zapowiedzi ST. Prorocy obwieszczali prawdę o zbawieniu ,z całej mocy, tak jak potrafili; żyli w tym ciele [...]. Wołają do naszych uszu, pobudzając do miłości owego miasta" ${ }^{44}$. W rzeczywistości Kościoła pielgrzymującego, ale już chwalebnego, wypełniają się obrazy odnowionej Jerozolimy, której powinno być podporządkowane wszystko, co doczesne, w tym także cesarstwo.

Jako środek skutecznej katechezy biskup Hippony wykorzystywał egzegezę typologiczną ${ }^{145}$. Kryterium hermeneutyczne o znamionach chrystologicznych przechodzi w sposób naturalny w kryterium eklezjologiczne. Doctor gratiae zachęcał, by wznieść się do poziomu duchowego pojmowania tekstu ${ }^{146}$. Był daleki od prymitywnej dosłowności, na co wskazują jego teksty antydonatystyczne. W jedności Kościoła zauważał podstawowy jego element jako powszechnej wspólnoty składającej się z ochrzczonych na ziemi i wybranych $w$ niebie ${ }^{147}$. Wielki Afrykańczyk opisał inne aspekty, które oznaczała rzeczywistość Kościoła - miasta Bożego ${ }^{148}$. Chodzi tu przede wszystkim o „cień” i „wizerunek” Kościoła w przyszłym świecie. To miasto świętych z siedzibą w niebiosach, jak to wyraża się w rozważaniach osnutych na kanwie Ps 49. Augustyn nie ma wątpliwości, że „Izrael to synowie Kościoła”. Ponadto wskazywał, że ,prawdziwy Syjon i prawdziwa Jerozolima [...], są wieczne i znajdują się w niebiosach: Jerozolima jest naszą matką, jako że nas zrodziła; jest wspólnotą świętych, która nas

143 Por. Augustinus Hipponensis, De civitate Dei XVII 3.

144 Augustinus Hipponensis, Enarrationes in Psalmos 147, 8.

145 Przede wszystkim była to jednak broń służąca w walce $\mathrm{z}$ manichejczykami.

146 Por. Augustinus Hipponensis, Tractatus in Johannem I 1.

147 Zob. H. Chadwick, The Church in Ancient Society: From Galilee to Gregory the Great, Oxford History of the Christian Church, Oxford 2001, s. 391-392.

148 „Proroctwa [...] odnoszące się do dwóch miast, przytaczają opowiadania o faktach mających wielkie znaczenie i które zajmowały i zajmują do tej pory badaczy Pisma Świętego, ponieważ oprócz tego, co jest tam napisane i wypełniło się w sposób historyczny w potomstwie Abrahama według ciała, należy szukać tam także tego, co na podstawie alegorii powinno się jeszcze dokonać w potomstwie według wiary” (Augustinus Hipponensis, De civitate Dei XVII 3). 
wychowała; jej częścią są pielgrzymujący, lecz większa część z nich znajduje się w siedzibie niebiańskiej" ${ }^{449}$.

W innym rozważaniu kaznodzieja utożsamia „Syjon” z Kościołem pielgrzymującym, a „Jerozolimę” - z chwalebną wspólnotą świętych w niebie.

Sam Bóg mieszka na Syjonie [...], który jest wyobrażeniem obecnego Kościoła: tak jak Jerozolima jest wyobrażeniem przyszłego Kościoła, czyli miasta świętych uczestniczących już w życiu anielskim [...]. W rzeczywistości „wypatrywanie” poprzedza „oglądanie” ${ }^{150}$, tak jak ten Kościół poprzedza tamten, który jest przyrzeczony ${ }^{151}$.

Obrazy biblijnej Jerozolimy i Syjonu zawierają w sobie główne rysy Kościoła jako rzeczywistości duchowej i eschatologicznej. Jest on pojmowany przez Augustyna w całej swej pełni, a nie tylko w swoim ziemskim aspekcie ${ }^{152}$. Kandydatom do chrztu oraz neofitom należy głosić, że znajdą „W Kościele wielu dobrych chrześcijan, prawdziwych obywateli niebiańskiej Jerozolimy", lecz pod warunkiem, że i oni będą żyć tą samą wiarą $^{153}$. To pozytywne myślenie, które jednak nie powinno przysłonić drugiej strony rzeczystości Kościoła. Bo przecież Kościół „we wszystkich swoich świętych, którzy są obywatelami Jerozolimy niebiańskiej (qui sunt cives Ierusalem caelestis), będzie zmuszony do niewoli u władców tego świata. Jednak [...] Kościół, jak Jerozolima, zostanie uwolniony od zamieszania tego świata [...]. Wszystko [to] wypełniało się w sposób przenośny (figurate)" 154 .

Dla Augustyna historia to misterny splot wydarzeń, gdzie znajduje się wiele aluzji, skomplikowanych motywów i symboli. Bóg bowiem to najlepszy architekt i niewysłowiony budowniczy.

Zadaniem członków Kościoła jest tworzenie duchowego gmachu i jednoczenie na wzór Boga, który ,zgromadził rozproszonych [z Jeruzalem]. Tak należy starać się, żeby teraz zostali zebrani rozproszeni, żeby w rękach

149 Augustinus Hipponensis, Enarrationes in Psalmos 49, 4-6.

150 Nawiązanie do wcześniej wyjaśnionej etymologii Jerozolimy i Syjonu.

151 Augustinus Hipponensis, Enarrationes in Psalmos 9, 12.

152 Por. Augustinus Hipponensis, Enarrationes in Psalmos 112, 3. „Civitas caelestis" to rzeczywistość mająca swoje miejsce w niebiosach. Mieszkańcami jej są wszyscy uświęceni, którzy byli, są i będą, jak również wszystkie święte duchy, które są na wysokościach i są posłuszne Panu" (Augustinus Hipponensis, De catechizandis rudibus XX 36).

153 Por. Augustinus Hipponensis, De catechizandis rudibus 7.

154 Augustinus Hipponensis, De catechizandis rudibus 21. Kanwę rozważań Augustyna stanowią opisy proroka Jeremiasza, które w sposób przenośny odnoszą się do Kościoła Chrystusowego. 
Artysty zostali wpasowani w budowlę"155. Wypełnienie się proroctw jest pewne, bowiem, „skoro (prorocy) śpiewali dla tamtego narodu [Izraela] i spełniło się, to czyż nie spełni się dla ludu chrześcijańskiego to, o czym śpiewają"156.

Po określeniu roli Jerozolimy Augustyn przechodzi do opisu rzeczywistości, którą ona oznacza. Jerozolima to przede wszystkim symbol, cień i obraz przyszłego Kościoła. Przecież ,niepłodne było wśród narodów państwo Boże, zanim nie powstał ten płód [Kościół]"157. Dzieje się tak, iż Chrystus poprzez dzieje stolicy narodu wybranego przygotowuje swoją oblubienicę bez skazy i zmarszczki ${ }^{158}$, mimo całego ogromu zła w ludzkich dziejach. Na tej podstawie twierdzi, że „oswobadza się królowa [Kościół] z Babilonu przez odrodzenie we wszystkich narodach i odchodzi od złego króla do najlepszego Władcy, od diabła do Chrystusa"159. Kościół posiada dwa wymiary: przyszły - „bez zmazy” i obecny, gdzie wmieszani są doskonali chrześcijanie i grzesznicy ${ }^{160}$.

W niektórych przypadkach łaciński doktor podkreśla różnicę istniejącą pomiędzy „Syjonem” symbolizującym Kościół pielgrzymujący ${ }^{161}$ a „Jerozolimą" stanowiącą odwieczne miasto Boże ${ }^{162}$. Autor De civitate Dei odwołuje się do obrazu „Kościoła otwartego”, czyli takiego, który jeszcze nie został oddzielony od zamieszania tego świata ${ }^{163}$. Według wy-

155 Augustinus Hipponensis, Enarrationes in Psalmos 146, 4.

156 Augustinus Hipponensis, Enarrationes in Psalmos 148, 5.

157 Augustinus Hipponensis, De civitate Dei XVII 4.

158 W nawiązaniu do Iz 45,8 Augustyn pisze, że Jerozolima „zstąpiła z niebios, od samego początku, od kiedy jej mieszkańcy zaczęli wzrastać w liczbę [...]. Na sądzie Bożym, który będzie ostateczny i [stanie się] dziełem Jego Syna, Jezusa Chrystusa, dzięki Bożemu darowi objawi się jej blask tak potężny i tak nowy, że nie pozostawi żadnego śladu starości”. Augustinus Hipponensis, De civitate Dei XX 17.

159 Augustinus Hipponensis, De civitate Dei XVII 16.

160 Por. Augustinus Hipponensis, Enarrationes in Psalmos 25, 2, 5; Augustinus Hipponensis, De doctrina christiana II 32.

161 Por. U. Occhialini, La speranza della Chiesa pellegrina. Teologia della speranza nelle „Ennarrationes in Psalmos” di S. Agostino, Assisi 1965.

162 Por. niektóre szczegóły w: Augustinus Hipponensis, Enarrationes in Psalmos 9, 12. W De civitate Dei to rozróżnienie nie występuje. Zob. Augustinus Hipponensis, De civitate Dei I 35; XIX 17.

163 Por. Augustinus Hipponensis, Enarrationes in Psalmos 136, 2: „Jeśli jesteśmy mieszkańcami Jerozolimy, a to oznacza to samo co «Syjon», a musimy żyć na tej ziemi w zamieszaniu obecnego świata w teraźniejszej Babilonii, gdzie nie mieszkamy jako obywatele, ale gdzie trzyma się nas jako więźniów. Trzeba, byśmy nie tylko wyśpiewali to, co [zostało] powiedziane w Psalmie, lecz i tym żyli. Czyni się to z głębokim natchnieniem serca pragnącego w pełni i pobożnie wieczystego miasta”. 
rażenia używanego przez Augustyna w jego kazaniach Kościół ,jest teraz budowany [...]; będzie się uświęcał aż do końca świata"164. W założeniach eklezjologicznych hippończyka aspekt wspólnotowy wysiłku podejmowanego na drodze prowadzącej do królowania w niebiańskim Jeruzalem spełnia zasadniczą rolę. Wielkość św. Augustyna widać także w tym, że nie pozwalał narzucić tematyki swoich rozważań. Nawet w kontekstach polemicznych rozszerzał perspektywę i harmonizował podejmowane refleksje z całością swojej wizji egzegetycznej, teologicznej i duchowej.

\section{Zakończenie}

Niektóre wątki polemiki donatystycznej potwierdzają fakt, iż dla chrześcijan pierwszych wieków Jerozolima nie była jedynie miejscem geograficznym wymienianym wielokrotnie na kartach Pisma Świętego. „Miasto wielkiego Króla" (por. Mt 5,35) stanowiło bowiem nośnik treści teologicznych i duchowych. Refleksje nawiązujące do świętego miasta pojawiają się w egzegezie biblijnej, refleksji filozoficznej i teologicznej. Niemniej ważne w tej kwestii było przepowiadanie Słowa Bożego i podstawowa katecheza.

Wizja Jerozolimy w odniesieniu do Kościoła nie tylko świadczy o szerokich zainteresowaniach eklezjologicznych autorów z kręgu Afryki Północnej, lecz także o ich eklezjalnym podejściu do faktów i obrazów biblijnych. Niejedno z kontrowersyjnych wydarzeń związanych z historią świętego miasta zostaje wyjaśnionych $\mathrm{w}$ duchu wiary, odnośnie do nadprzyrodzonej roli Kościóła i jego rzeczywistości ziemskiej. Biblia nie tylko ukazuje różne oblicza Kościoła, lecz to we wspólnocie ochrzczonych fakty odnoszące się do Jerozolimy nabierają głębszych znaczeń i są aktualizowane. Kontekst eklezjalny gwarantował głębsze odczytywanie natchnionych ksiąg Biblii.

Obok tej charakterystyki istniała spekulacja nastawiona na rzeczywistość ziemskiej Jerozolimy, otaczanej szacunkiem przez donatystów. Specyficzne elementy pojawiały się w egzegezie fragmentów proroctw psalmów i NT. Wkomponowywano je nie tylko w doktrynę eklezjologiczną, lecz również w inne kwestie. Eklezjologia łączyła się jednak z obrazem Jerozolimy w sposób najbardziej kompleksowy i organiczny. Donatyzm i powiązane $z$ nim refleksje o tym świadczą. Ten ruch powinien być postrzegany nie tylko jako zjawisko historyczno-społeczne czy dyscyplinar-

164 Por. Augustinus Hipponensis, Sermones 27, 1; 116, 7; 336, 1. W De civitate Dei hippończyk oświadcza, że Kościół jest już obecnie królestwem Chrystusa, chociaż nie należy identyfikować go z państwem Bożym. Zob. Augustinus Hipponensis, De civitate Dei XX 9. 
ne. Również spektrum doktrynalne nie powinno być zredukowane do wybranych, najbardziej charakterystycznych kwestii. Problemy eklezjologiczne zajmowały $\mathrm{w}$ dyskusjach $\mathrm{z}$ donatystami niepoślednią rolę. Sprzyjało temu ukierunkowanie eklezjologii w rzymskiej Afryce. Niepośledni wkład wnieśli tacy autorzy, jak Optat z Milewy i Tykoniusz. Ich dorobek w sferze egzegetyczno-teologicznej pozwolił św. Augustynowi usytuować konflikt donatystyczny na płaszczyźnie doktrynalnej. Hippończyk potrafił stworzyć w miarę spójny obraz Kościoła, zgodny zresztą z przekazem biblijnym i katolickim. Późniejsi Ojcowie łacińscy starali się nie odchodzić od tego, co znajdywali w spuściźnie tego wielkiego Doktora.

\title{
The Ecclesiological Symbolism of Jerusalem and the Anti-Donatist Controversy in Roman Africa
}

(summary)

The present article analyses to which extent the African authors had got used of the image of Jerusalem in the period of their polemic with the Donatists. It is well known that one of the focal points of the Donatist controversy concerned ecclesiology. There is a great number of Church's images occurring in the works of Christian authors, but it seems that a symbol of Jerusalem is however predominant. The city of God, an image of the Church, revealed itself as an earthly and celestial reality, including both the historical sphere and transcendence. Already in the process of forming ecclesiology in Nord Africa had a particular physiognomy with elements assimilated and altered by the Donatist sect. The reflections of Tyconius and Optatus of Milevi took on considerable significance and stood the origin of catholic's inspiration and argumentation. St. Augustine of Hippo placed the conflict with the Donatists not only on the practical and disciplinary context but above all on the doctrinal level. His ecclesiology proved to be coherent and compact. The bishop of Hippo found his basis on the biblical level and the traditional doctrine. In the anti-Donatist literature, it can be observed a certain predilection for a particular set of scriptural quotations used by various authors as an argument and as an illustration to support the thought concerning the universality of the Church. The topic of Jerusalem played here the crucial role.

Keywords: Church; Roman Africa; Donatist controversy; Ecclesiology; Jerusalem; Zion; Tyconius; Optatus of Milevi; Augustine of Hippo

\section{Symbolika eklezjalna Jerozolimy a polemika antydonatystyczna w Afryce Rzymskiej}

\author{
(streszczenie)
}

Prezentowany artykuł przedstawia, w jakim zakresie chrześcijańscy pisarze rzymskiej Afryki posługiwali się metaforą Jerozolimy $\mathrm{w}$ polemikach $\mathrm{z}$ donatystami. Wiadomo, 
że kluczowym punktem w tej dyskusji była kwestia eklezjologiczna. Niewątpliwie w literaturze patrystycznej pojawiało się wiele figur Kościoła, lecz wydaje się, że symbol Jerozolimy cieszył się znaczną popularnością. Miasto Boże, jako obraz Kościoła, jawiło się w swojej ziemskiej i niebiańskiej rzeczywistości. Zawierało w sobie zarówno sferę historyczną, jak i transcendentną. W procesie swojego formowania się w północnej Afryce eklezjologia nabierała specyficznych rysów. Były to elementy, które donatyści często sobie przyswajali i dostosowywali do swoich przekonań. Refleksje Tykoniusza i Optata z Milewy nabrały w tym kontekście szczególnego znaczenia. W pewnym sensie stanęły one u początków katolickiej interpretacji niektórych prawd o Kościele. W swojej argumentacji natomiast św. Augustyn z Hippony umieścił konflikt z donatystami nie tylko na płaszczyźnie praktycznej czy dyscyplinarnej, ale przede wszystkim na poziomie doktrynalnym. Eklezjologia biskupa Hippony ma zwarty i konsekwentny charakter. Ten wielki Ojciec Kościoła osadził swoją refleksję na fundamencie biblijnym i prawowierności doktryny. W literaturze antydonatystycznej można zauważyć pewne preferencje, jeśli chodzi o wybór świadectw biblijnych stosowanych przez różnych autorów jako argumenty lub ilustracje nauczania o powszechności Kościoła. Konkretny i duchowy obraz Jerozolimy odgrywał tutaj kluczową rolę.

Słowa kluczowe: Kościół; rzymska Afryka; donatyści; eklezjologia; Jerozolima; Syjon; Tykoniusz; Optat z Milewy; Augustyn z Hippony

\section{Bibliografia}

\section{Źródła}

Ambrosius, De fide (ad Gratianum Augustum), ed. O. Faller, CSEL 78, Wien 1962, tł. I. Bogaszewicz, Ambroży z Mediolanu, O wierze do cesarza Gracjana, Warszawa 1970.

Ambrosius, De paenitentia, ed. R. Gryson, SCh 179, Paris 1971, tł. W. Szołdrski, Św. Ambroży, Wybór pism, PSP 7, Warszawa 1971.

Ambrosius, Explanatio Psalmorum XII, ed. M. Petschenig - M. Zelzer, CSEL 64, Wien 1999.

Athanasius Alexandrinus, Expositiones Psalmorum, PG 27, 55-590.

Augustinus Hipponensis, Epistula ad catholicos de secta donatistarum, ed. A. Lombardi, NBA 15/2, Roma 1999, s. 394-525.

Augustinus Hipponensis, Contra Cresconium grammaticum et Donatistam, ed. E. Cavallari, NBA 16/1, Roma 2002, s. 40-443.

Augustinus Hipponensis, Contra epistulam Parmeniani, ed. A. Lombardi, NBA 15/1, Roma 1998, s. 62-241.

Augustinus Hipponensis, Contra Faustum Manichaeum, ed. J. Zycha, CSEL 25/1, Vindobonae 1891, s. 251-797, tł. J. Sulowski, Św. Augustyn, Przeciw Faustusowi, PSP 55-56, Warszawa 1991. 
Augustinus Hipponensis, De catechizandis rudibus, ed. J.B. Bauer, CCL 46, Turnhout 1969, tł. W. Budzik, Św. Augustyn, Początkowe nauczanie katechizmu, POK 10, Warszawa 1952, s. 1-60.

Augustinus Hipponensis, De civitate Dei, ed. D. Gentili, NBA 5 B-C, Roma 1989, tł. W. Kornatowski, Św. Augustyn, O państwie Bożym przeciw poganom ksiag XXII, t. 1-2, Warszawa 1977.

Augustinus Hipponensis, De doctrina christiana, ed. M. Naldini - L. Alici - A. Quacquarelli - P. Grech - V. Tarulli, NBA 8, Roma 1992, tł. J. Sulowski, Św.Augustyn, O nauce chrześcijańskiej, PSP 22, Warszawa 1989, s. 17-134.

Augustinus Hipponensis, De quantitate anima, PL 32, 1035-1080.

Augustinus Hipponensis, Enarrationes in Psalmos, ed. V. Tarulli - T. Mariucci - F. Monteverde, NBA 27-28, Roma 1976-1977, tł. J. Sulowski, Św. Augustyn, Objaśnienia Psalmów, PSP 39-42/1, Warszawa 1986.

Augustinus Hipponensis, Epistolae, ed. T. Alimonti - L. Carrozzi, NBA 21-23A, Roma 1971-1992, tł. W. Eborowicz, Augustyn, Listy (1-75), Pelplin 1991.

Augustinus Hipponensis, In Evangelium Joannis tractatus CXXIV, ed. O. Campagna E. Gandolfo - V. Tarulli - F. Monteverde, NBA 24/1-2, Roma 2004, tł. W. Szołdrski - W. Kania, Św. Augustyn, Homilie na Ewangelie i Pierwszy list Jana, PSP 15, Warszawa 1977.

Augustinus Hipponensis, Sermones, ed. P. Bellini - L. Carrozzi - F. Cruciani, NBA 2934, Roma 1983-1989, tł. J. Jaworski, Św. Augustyn, Wybór mów, PSP 12, Warszawa 1973.

Cyprianus, De Ecclesiae catholicae unitate, ed. M. Bévenot, CCL 3, Turnhout 1972, tł. J. Czuj, O jedności Kościoła katolickiego, POK 19, Poznań 1937, s. 171-193.

Cyprianus, Testimonia ad Quirinum, ed. R. Weber, CCL 3, Turnhout 1972, s. 3-179.

Cyrillonas, Carmina, ed. G. Bickell, Die Gedichte des Cyrillonas nebst einigen anderen syrischen Inedits, „Zeitschrift der Deutschen Morgenländischen Gesellschaft” 27 (1873) s. 566-625.

Cyrillus Alexandrinus, In Isaiam, PG 70, 9-1450.

Cyrillus Hierosolymitanus, Catecheses, ed. G.C. Reischl - J. Rupp S. Cyrilli Hierosolymitani archiepiscopi opera quae supersunt omnia, t. 1-2, Monachium 1848-1860, tł.W. Kania, Św. Cyryl Jerozolimski, Katechezy przedchrzcielne i mistagogiczne, BOK 14, Kraków 2000.

Epiphanius, Panarion (34-64), ed. K. Holl, GCS 31, Leipzig 1922.

Gennadius Massiliensis, De viris inlustribus, ed. E.C. Richardson, TU 14 A, Leipzig 1898. Gregoriusturonensis, Liber in gloria Martyrum, PL 71, 705-800.

Hieronymus Stridonensis, Commentarii in evangelium Matthaei, ed. D. Hurst - M. Adriaen, CCL 77, Turnhout 1969, tt. J. Korczak, Komentarz do Ewangelii wedtug św. Mateusza, ŹMT 46, Kraków 2008.

Hilarius Pictaviensis, Tractatus super Psalmos (I-XCI), ed. J. Doignon, CCL 61, Turnhout 1997. 
Itinerarium Burdigalense, ed. P. Geyer, CSEL 39, Vindobonae 1898, s. 1-33, t1. P. Iwaszkiewicz, Do Ziemi Świętej. Najstarsze opisy pielgrzymek (IV-VIII w.), OŻ 13, Kraków 1996, s. 79-86.

Optatus Afrus, De schismate donatistarum adversus Parmenianum, ed. M. Labrousse,

SCh 412, Paris 1995, tł. A. Gołda, Optat z Milewy, Traktat przeciw donatystom, ŹMT 56, Kraków 2011.

Origenes, In Ezechielem homiliae, ed. M. Borret, SCh 352, Paris 1989, tł. S. Kalinkowski, Orygenes, Homilie o księdze Ezechiela, ŹMT 16, Kraków 2000, s. 73-214.

Origenes, In Iesu Nave homiliae, ed. A. Jaubert, SCh 71, Paris 1960, tł. S. Kalinkowski, Orygenes, Homilie o Księdze Jozuego, w: Orygenes, Homilie o Księgach Liczb, Jozuego, Sędziów, PSP 34/2, Warszawa 1986, s. 3-137.

Origenes, In Jeremiam homiliae, ed. P. Husson - P. Nautin, SCh 232; 238, Paris 19761977.

Paulinus Nolanus, Epistulae, ed. G. Hartel, CSEL 29, Vindobonae 1894.

Ps-Cyprianus, De duobus montibus, ed. B. Burini, Pseudo Cipriano, I due monti Sinai e Sion. De duobus montibus, Biblioteca Patristica 25, Firenze 1994.

Ps-Hieronymus, Expositio Evangelii secundum Marcum, ed. M. Cahill, CCL 82, Turnhout 1997.

Sermones Escorial, ed. A. Hamman, PLS 4, s. 669-740.

Tertullianus, De praescriptione haereticorum, ed. R.F. Refoulé, CCL 1, Turnhout 1954, s. 185-224, tł. E. Stanula, Przeskrypcja przeciw heretykom, PSP 5, Warszawa 1970, s. $40-78$.

Tertullianus, De resurrectione carnis, ed. J.G.P. Borleffs, CCL 2, Turnhout 1954, s. 9191012.

Theodoretus Cyrensis, Explanatio in Ezechielem, PG 81, 807 A-1256 B.

Theodoretus Cyrensis, Interpretatio in Abdiam, PG 81, 1709 A-1718 D.

Theodoretus Cyrensis, Interpretatio in Jeremiam, PG 81, 495-806.

Theodoretus Cyrensis, Interpretatio in Psalmos, PG 80, 857-1998.

Tyconius Afer, Expositio Apocalypseos, ed. R. Gryson, CCL 107 A, Turnhout 2011, t1. M. Niewiadomska, Fragmenty Tykoniusza, w: Pierwsze łacińskie komentarze do Apokalipsy. Hipolit, Wiktoryn, Hieronim, Tykoniusz, Florilegium. Studia Classica, Mediaevalia et Neolatina 10, red. D. Budzanowska - W. Linke, Warszawa 2011, s. 167-229.

Tyconius Afer, Liber regularum, ed. F.C. Burkitt, The Book of Rules of Tyconius, Texts and Studies III/1, Cambridge 1894.

\section{Opracowania}

Adamiak S., Eklezjologiczny charakter Komentarza do Apokalipsy donatysty Tykoniusza, BPTh 5 (2012) s. 151-162.

Adamiak S., Deo Laudes. Historia sporu donatystycznego, Warszawa 2019.

Bagatti B., Il Golgota e la croce, Jerusalem 1978. 
Budzanowska D., O rekapitulacji wedtug Tykoniusza, WST 26/2 (2013) s. 77-92.

Budzanowska-Weglenda D., Tykoniusz i jego reguty egzegezy biblijnej. Monografia literacka, Warszawa 2015.

Cameron M., Augustine's Use of the Song of Songs against the Donatists, w: Augustine Biblical Exegete, ed. F. van Fleteren - J.C. Schnaubelt, New York 2001, s. 99-127.

Chadwick H., The Church in Ancient Society: From Galilee to Gregory the Great, Oxford History of the Christian Church, Oxford 2001.

Clerici A., Sant'Agostino. La Chiesa da Eva alla città di Dio, Roma 2000.

Czyżewski B., Ocena Liber regularum Tykoniusza przez św. Augustyna, „Studia Bydgoskie" 3 (2009) s. 235-247.

De Bruyn T.S., Pelagius's Commentary on St. Paul's Epistle to the Romans, Oxford Early Christian Studies 4, Oxford 1993.

Folliet G., La typologie du ,,sabbat” chez saint Augustin. Son interprétation millénariste entre 389 et 400, REAug 2 (1956) s. 371-390.

Forstner D., Świat symboliki chrześcijańskiej. Leksykon, Warszawa 2001.

Frend W.H.C., The Donatist Church. A Movement of Protest in Roman North Africa, Oxford 1952.

Gaumer M.A., Augustine's Cyprian. Authority in Roman Africa, Leiden - Boston 2016.

Gaumer M.A., The Evolution of Donatist Theology as Response to a Changing Late Antique Milieu, „Augustiniana” 58/3-4 (2008) s. 201-233.

Gilson E., Wprowadzenie do nauki świętego Augustyna, Warszawa 1953.

Grabau J.L., John 4:23-24 in North African Preaching, „Scrinium” 13 (2017) s. 138-140.

Hamman A.G., Życie codzienne w Afryce Pótnocnej w czasach św. Augustyna, tł. M. Stafiej-Wróblewska - E. Sieradzińska, Warszawa 1989.

Hoover J.A., Decoding the Donatist Capitula, North American Patristics Society Conference, Chicago 2018, https://www.academia.edu/36497476/Decoding_the_Donatist_ Capitula [08.04.2019].

Hoover J.A., The Donatist Church in an Apocalyptic Age, Oxford Early Christian Studies, Oxford 2018.

Jóźwiak S., Państwo i Kościół w pismach św. Augustyna, Lublin 2004.

Kaczmarek T., Augustyn - Ekumenista, SWł 15 (2013) s. 23-36.

Kaswalder P.A., Onomastica biblica. Fonti scritte e ricerca archeologica, Collectio Minor 40, Jerusalem 2002.

Lauras A., Deux cites, Jérusalem et Babylone. Formation et évolution d'un thème central du , De Civitate Dei”, „La Ciudad de Dios. Revista Augustiniana de cultura e investigación", 167/1 (1954) s. 117-150.

Lauras A. - Rondet H., Le thème des deux cités dans l'oeuvre de saint Augustin, Études Augustinienes, Paris 1953, s. 99-160.

Lombardi A., L'ecclesiologia di S. Agostino nella polemica donatista, w: I conflitti religiosi nella scena pubblica, ed. L. Alici, Roma 2015, s. 225-273.

Marone P., L'esegesi biblica di Ottato di Milevi, Studi e Proposte 5, Roma 2008. 
Mazzucco C., La pace come unità della Chiesa e le sue metafore in Ottato di Milevi, CCC 12 (1991) s. 173-211.

Mazzucco C., Ottato di Milevi in un secolo di studi: problemi e prospettive, Università degli studi di Torino. Dipartimento di filologia, linguistica e tradizione classica 3, Bologna 1993.

Occhialini U., La speranza della Chiesa pellegrina. Teologia della speranza nelle „Ennarrationes in Psalmos" di S. Agostino, Assisi 1965.

Oort van J., Jerusalem and Babylon. A Study into Augustine's City of God and the Sources of his Doctrine of the Two Cities, Leiden 1991.

Paczkowski M.C., Zbawienie i jego geograficzny wymiar w patrystycznej interpretacji Ps 74(73), 12, BPTh 11/1 (2018) s. 35-56.

Quacquarelli A., La concezione della storia nei Padri prima di S. Agostino, Roma 1955.

Romero Pose E., Medio siglo de estudios sobre el donatismo (De Monceaux a nuestros dias), „Salmaticensis” 29 (1982) s. 81-99.

Romero Pose E., El tratado „, de montibus Sina et Sion” y el donatismo, „Gregorianum” 63 (1982) s. 273-299.

Simonetti M., Między dosłownościa a alegoria. Przyczynek do historii egzegezy patrystycznej, tł. T. Skibiński, Kraków 2000.

Tilley M., Sustaining Donatist Self-Identity. From the Church of the Martyrs to the Collecta of the Desert, JECS 5/1 (1997) s. 21-35.

Tilley M., The Bible in Christian North Africa. The Donatist World, Minneapolis 1997.

Zagórski D., Commendavit nobis Dominus oves suas. Pasterska troska o wiernych w świetle Sermones św. Augustyna, Toruń - Pelplin 2013.

Zocca E., L'identità cristiana nel dibattito tra cattolici e donatisti, ASE 21/1 (2004) s. 109-130. 